\title{
HEINONLINE
}

Citation: 52 Stan. L. Rev. 547 1999-2000

Content downloaded/printed from

HeinOnline (http://heinonline.org)

Thu Aug 16 13:08:42 2012

-- Your use of this HeinOnline PDF indicates your acceptance of HeinOnline's Terms and Conditions of the license agreement available at http://heinonline.org/HOL/License

-- The search text of this PDF is generated from uncorrected OCR text.

-- To obtain permission to use this article beyond the scope of your HeinOnline license, please use:

https://www.copyright.com/ccc/basicSearch.do?

\&operation $=$ go\&search Type $=0$

\&lastSearch $=$ simple\&all $=0$ \& \& titleOrStdNo $=0038-9765$

Retrieved from DiscoverArchive,

Vanderbilt University's Institutional Repository

By permission of the Board of Trustees of the Leland Stanford Junior University, from the Stanford Law Review at 52 Stan. L. Rev. 547

1999-2000. For more information visit http://www.stanfordlawreview.org. 


\title{
ARTICLES
}

\section{Corporate Risk Analysis: A Reckless Act?}

\author{
W. Kip Viscusi*
}

Balancing of risk and cost lies at the heart of standard negligence tests and policy analysis approaches to government regulation. Notwithstanding the desirability of using a benefit-cost approach to assess the merits of safety measures, in many court cases juries appear to penalize corporations for having done a risk analysis in instances in which the company decided not to make a safety improvement after the analysis indicated the improvement was unwarranted. Automobile accident cases provide the most prominent examples of such juror sanctions. This paper tests the effect of corporate risk analyses experimentally by using a sample of almost 500 juror-eligible citizens. Each individual considered an automobile accident scenario, but these scenarios differed in terms of whether the company undertook a risk analysis and in terms of the nature of the risk analysis. Somewhat surprisingly, even sound benefit-cost analyses of safety measures did not reduce the likelihood of punitive damages. If a company follows the procedures used by government agencies and uses a higher value of life in its analyses, the penalty levied on the corporation increases. Internal use of higher value of life numbers serves as an anchor that boosts rather than reduces jury awards.

[Editorial note-the Stanford Law Review has solicited comments to this piece that will be published in forthcoming issues.]

* John F. Cogan, Jr. Professor of Law and Economics, Director of the Program on Empirical Legal Studies, Harvard Law School, Cambridge, MA 02138, phone: 617-496-0019, fax: 617-4953010, e-mail: kip@law.harvard.edu. This research was supported by the Sheldon Seevak Research Fund, the Olin Center for Law, Economics, and Business at Harvard Law School, and a grant from the Exxon Corporation. Jahn Hakes, Amy Semet, Nathan Drake, and Edwin U provided valuable comments and research assistance. Gary Schwartz and Reid Hastie provided excellent comments. 


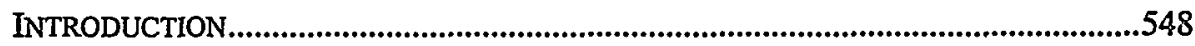

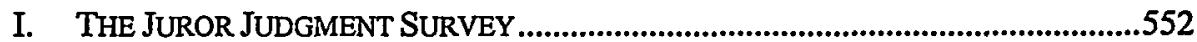

II. THE RISK-BALANCING REFERENCE POINT ...................................................559

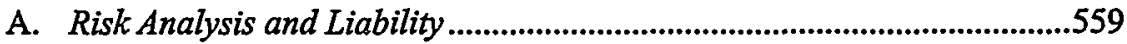

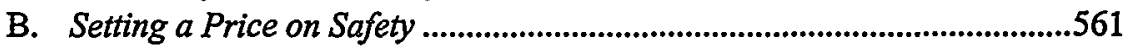

C. Problems in Ex Post Jury Assessments of Risk Analyses............................563

D. Risk-Utility Analysis ...............................................................................566

E. Risk Analysis After Accidents .............................................................567

III. BENEFIT-COST ANALYSES AT FORD MOTOR COMPANY ..................................568

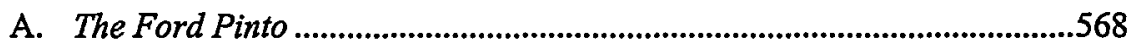

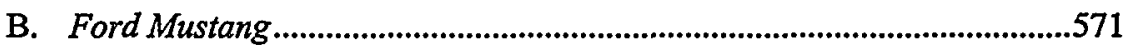

C. Ford's Seatbelt Failures.......................................................................572

IV. PRODUCT-RISK ANALYSES AT GENERAL MOTORS..........................................573

V. PHARMACEUTICALS-RISK ANALYSIS WITH GOVERNMENT SUPERVISION ......579

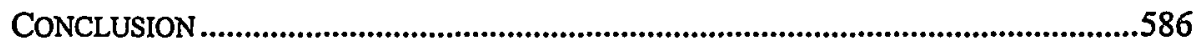

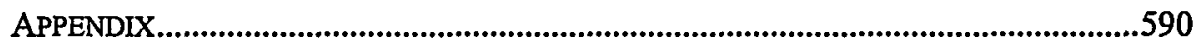

\section{INTRODUCTION}

In 1999, a Los Angeles jury imposed a $\$ 4.8$ billion punitive damages award on General Motors for a case involving severe burns to passengers in a 1979 Chevrolet Malibu. 1 This award, which is the largest punitive award ever in a personal injury case, 2 arose in part because the company had undertaken an explicit analysis of the types of fire risks and design change costs associated with burn injuries. 3 The main issue raised by this award is whether, in fact, a corporation is being irresponsible if it undertakes a risk analysis and chooses not to make an unbounded cost commitment to safety.

On a personal level, the approach of accepting risk tradeoffs is implicit in our daily lives. We take chances all the time. We ride in motor vehicles, fly on planes, eat potentially risky foods, and live in an environment that is not risk-free. Some tradeoffs of this kind are inevitable as we seek to strike an appropriate balance between the harm inflicted by risks and the benefits such activities offer for our lives. The task for the individual is to make

1. See Andrew Pollack, Paper Trail Haunts GM After It Loses Injury Suit: An Old Memo Hinted at the Price of Safety, N.Y. TIMES, July 12, 1999, at A12 [hereinafter Pollack, Paper Trail]; Andrew Pollack, \$4.9 Billion Jury Verdict in GM Fuel Tank Case: Penalty Highlights Cracks in Legal System, N.Y. TMME, July 10, 1999, at A8 [hereinafter Pollack, Jury Verdict].

2. See Pollack, Paper Trail, supra note 1, at A12; Ann W. O'Neill, Henry Weinstein \& Eric Malnic, GM Ordered to Pay $\$ 4.9$ Billion in Crash Verdict Liability, L.A. TIMES, July 10, 1999, at A1 ("Legal experts said the verdict was the largest ever in a personal injury case.").

3. See Pollack, Paper Trail, supra note 1, at A12. 
those personal decisions that confer sufficient benefits to outweigh the associated risks.

When faced with options that have different levels of safety, we often pay a higher price for safer products, though not without limit. Millions of consumers purchase cars with antilock brakes and protective side air bags, but few of us have such an unlimited concern for safety that we purchase a tank-like Hummer vehicle. The degree of concern for safety that consumers manifest in turn sends signals to corporations in terms of the kinds of goods and levels of safety that we value. The risk tradeoffs that we are willing to make in effect set the price for safety in the market and provide guidance to corporations, which must supply the products and services we purchase. If corporations generate products that create more hazards than we want to bear given the product price, or include unnecessary safety features that we do not value, then the product risk mix will not be successful in the marketplace. Thus, the task of corporations is to assess the risks of products and activities and to determine which safety efforts are worthwhile and in line with consumer preferences. For risks arising in a market trade with the party bearing the risk, informed consumer choices will lead to efficient risk levels. Not all risks, however, are priced in the market. Environmental hazards are an example of risks that are not. In this instance, government regulation can be used to provide appropriate incentives.

The formal mechanism for making tradeoff judgments is a risk analysis that outlines the pluses and minuses of different safety options. Risk analysis consists of a variety of different levels of analyses. First, risk analysis involves assessing the magnitude of the hazard. Is it a serious threat or a minor background risk? Second, are the risk-reducing policies selected costeffective; i.e., do they achieve the greatest risk reduction possible for the amount of funds expended? Third, do the policies pass a benefit-cost test? Do the societal benefits of risk reduction outweigh the costs? Firms' interest in profits will lead them to choose the most cost-effective option, and risk awareness by consumers will lead firms to adopt risk reduction efforts that pass a benefit-cost test. However, in the absence of informed and rational choice, firms may not adopt all safety improvements that are efficient in terms of benefits exceeding costs-a relationship that is tested through negligence tests in the court and benefit-cost analyses in the policy arena. ${ }^{4}$

4. See A. Mrtchell POLINSKY, AN INTRODUCTION TO LAW AND ECONOMICS 41-42 (2d ed. 1989) (arguing that courts choose a standard of care in negligence actions that corresponds to the efficient outcome); RICHARD A. POSNER, ECONOMIC ANALYSIS OF LAW 288-89 (5th ed. 1998) (arguing that in the common law system, wrongful conduct is equivalent to inefficient conduct); John W. Wade, On The Nature of Strict Tort Liability for Products, 44 Miss. L.J. 825, 837-38 (1973) (offering a list of factors to weigh when determining whether a product is "unreasonably dangerous"). See generally STEPHEN BREYER, BREAKING THE VICIOUS CIRCLE: TOWARD EFFECTIVE RISK REGULATION (1993) (proposing new institutional solutions for calculating, regulating, and reducing health risks). 
Any systematic attempt to trade off costs and risk-reduction benefits may appear to be a cold-blooded calculation invented by economists. 5 Seeking the right tradeoff between risk and cost is not an abstract economic exercise, but lies at the heart of the real choices that must be made. Indeed, we want corporations to think about risks in a systematic manner and to undertake such calculations to ensure that there is appropriate risk balancing that is sufficiently protective. We all benefit when corporations select the level of safety that correctly reflects our own concern with safety and the costs of providing it. The merits of the analysis and the ultimate balance struck should be the main manner of concern, not whether undertaking a systematic analysis allegedly reflects a cold-blooded attitude towards human life. Of course, the fact that companies have undertaken such balancing does not imply that they should be vindicated on economic grounds. Even armed with an extensive risk analysis, companies may fail to make sufficiently protective decisions. But liability for corporate behavior should hinge on the risk and cost decisions, not on whether the firm undertook a risk analysis. We want to encourage corporations to do such systematic thinking about risk and cost. The fact that they have done such analyses and have perhaps erred in the process should not itself be regarded as a reckless act. Indeed, our society will only become safer if we think carefully about safety and make the right choices given our limited resources.

A major difficulty arises if a company that undertakes a risk analysis and yet proceeds with a potentially dangerous act or a risky product triggers a bias among jurors against it simply for having undertaken the risk analysis. Such biases might be especially pronounced in situations in which there is a general anti-corporate bias or a suspicion of the motives underlying corporate decisions. ${ }^{6}$ Undertaking explicit risk-cost tradeoffs, which in effect balance lives lost and environmental damage against monetary costs, may offend jurors' sensibilities. The fact that a company has undertaken a risk analysis-even a sound analysis-may lead jurors to award punitive damages rather than compensatory damages alone. The highly charged atmos-

5. See Memorandum in Support of the State's Motion for Ruling in Limine, or, Alternatively, for Partial Summary Judgment at 21, 23, In Re Mike Moore, Attorney General ex rel. State of Mississippi Tobacco Litig. (filed Aug. 11, 1995, in the Chancery Court of Jackson County, Miss.) (No. 94-1429) (on file with the Stanford Law Review) (describing my argument that costs saved as a result of the deaths allegedly caused by smoking should offset the state's restitutionary claims for the cost of treating cigarette-related diseases as "base, evil and corrupt," "akin to robbing the graves of the Mississippi smokers who died from tobacco-related illness," and "an offense to human decency, an affront to justice, uncharacteristic of civilized society, and unquestionably contrary to public policy").

6. See Peter Aronson, David E. Rovella \& Bob Van Voris, Jurors: A Biased, Independent Lot, NAT'L L.J., Nov. 2, 1998, at A1 (stating that a 1998 National Law Journal-DecisionQuest poll found that people often think the worst of corporate actions: "Three out of four people said they believe executives of big companies often try to cover up harm they do, and more than one in five said they could not be a fair juror if a tobacco company were one of the parties to a case they were considering."). 
phere of many court proceedings often prompts juries to impose large awards to send corporations a message. Such message-sending has the purported intent of generating incentives for safety. As a former president of the Consumer Attorneys of California put it: "The purpose of punitive damages is to deter despicable acts by corporate America."

But what are these "despicable acts"? In some cases, the alleged despicable act may be the actual undertaking of a risk analysis itself rather than a failure to strike an appropriate risk-cost balance in its product safety or environmental risk choices. A prominent example is the recent case of Sergio Jimenez, who was killed in his Chrysler Minivan because of an allegedly defective rear-door latch. In 1994, Sergio Jimenez, who was six years old, was riding unbuckled in the back seat of a 1985 Dodge Caravan in Charleston, South Carolina. As his mother ran a red light, her van was struck on the side by a Honda that was traveling under fifteen miles per hour. The van rolled over, the rear door opened, and Sergio Jimenez was thrown to the street and died. The plaintiffs claimed that the door lock was defective, and more importantly, that Chrysler had analyzed the defect and failed to repair it. 8

Jimenez v. Chrysler Corp. led to a $\$ 250$ million punitive damages award against Chrysler Corporation.9 The company was faulted not only for the defective door latch, but also for trading off risk against cost. In Chrysler's view, the defect posed no significant risk, but the cost would have been $\$ 100,000$ for a one-time tooling cost, plus $\$ 0.50$ per vehicle for the new part. ${ }^{10}$ In such instances, jurors are unlikely to compare the costs and the expected benefits, given the probability of an accident. Instead, they may compare the $\$ 0.50$ per vehicle cost with an identifiable death, between which there is a stark difference. The plaintiff's attorneys demonized Chrysler's analysis in their post-trial memorandum: "Chrysler officials at the highest level coldbloodedly [sic] calculated that acknowledging the problem and fixing it would be more expensive, in terms of bad publicity and lost sales, than concealing the defect and litigating the wrongful death suits that inevitably would result."11

7. Wayne McClean, Suit-Happy California? It's a 'Myth', S.F. CHRON., Mar. 8, 1995, at A21; see also Alex Kozinski, The Case of Punitive Damages v. Democracy, Wall St. J., Jan. 19, 1995, at A18 (raising concerns about the role that large punitive damage awards play in shaping public policy).

8. See Nichole M. Christian, Angelo B. Henderson \& Asra Q. Nomani, Chrysler Is Told to Pay \$262.5 Million by Jurors in Minivan-Accident Trial, WALL. ST. J., Oct. 9, 1997, at A3.

9. See Jimenez v. Chrysler Corp., No. 2: 96-1269-11, 1997 WL 743644, at *1 (LRP Jury) (S.C. Oct. 8, 1997).

10. See Donald C. Dilworth, Fourteen Jurors Punish Chrysler for Hiding Deadly Defect, TRIAL, Feb. 1998, at 14.

11. Id. 
Suppose that the company did the analysis correctly, in a manner in line with contemporary sound and responsible economic principles. Would the existence of the risk analysis itself make jurors more likely to conclude that the corporation acted recklessly by placing excessively risky products on the market? To explore this issue, I present new empirical evidence based on an original survey that I undertook with almost 500 juror-eligible citizens. Ideally, jurors should take into account responsible risk-cost balancing. A corporate risk analysis that showed that the benefits of the safety improvement did not exceed the costs should not only eliminate the possibility of punitive damages, but also eliminate negligence-based claims. Unfortunately, any such analysis seems to have adverse effects. Undertaking even a sound risk analysis in line with that used by government regulators leads mock jurors to impose greater sanctions for risk decisions, despite the fact that these choices may have struck an appropriate risk-cost balance.

This behavior of mock jurors is not consistent with the intent of tort law. There are no existing legal provisions indicating that firms should be punished for having undertaken a risk analysis. The type of behavior reflected by the mock jurors is also borne out in actual cases, such as Jimenez $v$. Chrysler Corp. and other cases discussed below. A detailed review of instances in which firms have undertaken risk analyses indicates that such careful risk and cost assessments tend to affect firms adversely. The wellknown example involving the stigmatization of Ford following the release of the internal Ford Pinto safety documents has been followed repeatedly in more recent cases.

Adopting legal guidelines whereby defendants will not be adversely affected by having done a risk analysis may not be fully effective given jurors' susceptibility to hindsight bias. More sweeping legal reforms, such as taking punitive damages out of the hands of jurors ${ }^{12}$ or abolishing punitive damages altogether for corporate risk decisions, ${ }^{13}$ are needed.

\section{THE JUROR JUDGMENT SURVEY}

To explore how jurors react to the presence of corporate risk analyses of product hazards, I constructed a survey in which juror-eligible citizens considered alternative accident scenarios. Some mock jurors considered cases in which no benefit-cost analysis was performed, and other jurors considered

12. See Cass R. Sunstein, Daniel Kahneman \& David Schkade, Assessing Punitive Damages (with Notes on Cognition and Valuation in Law), 107 YALE L.J. 2071, 2121 (1998) ("There is good reason to believe... that if punitive damages are designed to produce optimal deterrence, juries should be eliminated.").

13. See W. Kip Viscusi, Why There Is No Defense of Punitive Damages, 87 GEO. L.J. 381 (1998); W. Kip Viscusi, The Social Costs of Punitive Damages Against Corporations in Environmental and Safety Torts, 87 GEO. L.J. 285 (1998). 
variants of a case in which the company did perform such an analysis. By comparing the responses of jurors across the different case treatments, I ascertained the incremental influence of undertaking an economic analysis.

The sample consisted of 489 adults. The appendix presents the sample characteristics in more detail. The sample population had a mean age of forty-five and a median education level of some college; two-thirds of the sample participants were female. Subjects were recruited to participate by a survey research firm in Phoenix, Arizona, which reimbursed them for taking part. Detailed multiple regression analyses, which control for the influence of demographics, yield similar results to the overall sample comparisons.

The study examined a variety of hypotheses, leading to the five different scenarios that will be discussed further below. Here I will outline the experimental structure and the principal hypotheses, which are summarized in Table 1. All scenarios involved a similar auto accident context. Scenario 1 is the baseline scenario, which will serve as the initial reference point. By comparing the results in the other scenarios with this control group, one can ascertain the incremental effect of the risk analysis manipulations as compared to the no-analysis case.

Table 2 outlines five hypotheses that can be tested using the juror results. Scenario 2 involves auto risks in which the cost-per-life-saved for greater safety is less than in Scenario 1, but there is no corporate risk analysis in either case. One should expect jurors to have a more favorable view of decisions to forego more expensive safety measures (in terms of cost-per-lifesaved). Comparing the results of Scenario 1 with Scenarios 3 through 5 indicates whether a jury views a corporate risk analysis as a responsible act or one worthy of punishment. Similarly, comparing Scenarios 3 and 4 provides a test of whether the type of corporate risk analysis matters. In particular, does it matter whether corporations use court awards as the reference point for assessing the cost of death or instead use a higher value consistent with government regulatory analyses? One should expect jurors to look favorably on corporations using the higher value. From a cognitive standpoint, however, a higher value might serve as an anchor that raises liability awards. Comparison of Scenarios 4 and 5 indicates whether company errors affect the risk assessment component of the analysis. Finally, all scenarios were run using both four deaths and ten deaths as the accident context to see whether higher absolute risk levels would lead jurors to impose greater sanctions on the company. Presumably, more accidents for any given level of operations should be viewed more adversely.

The key questions posed by the scenarios involving risk analyses are whether mock jurors levy punitive damages and, if so, in what amount. Scenario 2, in which no risk analysis was performed, exemplifies the substantive context of these decisions: 
A major auto company with annual profits of $\$ 7$ billion made a line of cars with a defective electrical system design. This failure has led to a series of fires in these vehicles that cause ten burn deaths per year. Changing the design to prevent these deaths would cost $\$ 10$ million for the 100,000 vehicles affected per year, or $\$ 100$ each. The company thought that there might be some risk from the current design, but did not believe that it would be significant. The company notes that even with these injuries, the vehicle has one of the best safety records in its class.

The courts have awarded each of the victim's families $\$ 800,000$ in damages to compensate them for the income loss and pain and suffering that resulted. After these lawsuits, the company altered future designs to eliminate the problem.

By indicating that the product was "defective," the intent was not to draw a legal conclusion, but simply to indicate that the system failed to operate in a completely safe manner. ${ }^{14}$ Moreover, even if the respondents concluded that a defect existed from a legal standpoint, that would be consistent with the award of compensatory damages. As indicated in the survey text, the court already had awarded compensatory damages, and the only concern was whether punitive damages were warranted.

The respondents then considered two questions. First, they were asked whether punitive damages should be awarded "to punish the company for reckless behavior." Second, if they chose to award such damages, they were asked for a dollar amount. They picked from the following possibilities: $\$ 100,000, \$ 1$ million, $\$ 10$ million, $\$ 100$ million, and some other amount selected by the respondent.

Different groups considered the five different scenarios summarized in Table 1. In much of the discussion below, these different scenarios will be pooled into broader categories, since there were no statistically significant differences among many of the major component groupings. The first broad category consists of the two scenarios in which the company did not perform a benefit-cost analysis of the product hazard. In Scenario 1, the company did not perform the analysis, but the cost-per-life-saved would have been $\$ 4$ million. In Scenario 2, reproduced in the text above, the details of the scenario were the same except that the cost-per-life-saved was $\$ 1$ million. One would expect that jurors would be more likely to levy punitive damages if the cost-per-life-saved were lower rather than higher because, presumably, companies would be more remiss if it were cheaper to provide a safe product. The expense to the company to provide greater product safety is less when the cost-per-life-saved is low, making safety expenditures more attrac-

14. For example, BLACK's LAW DICTIONARY 429 (7th ed. 1999) defines defect as: "[a]n imperfection or shortcoming, esp. in a part that is essential to the operation or safety of a product." The legal definition is not substantially different from the definition for the word's popular usage: "an imperfection that impairs worth or utility." WEBSTER'S NEW COLLEGIATE DICTIONARY 294 (1979). 
tive. Thus, there will be a broader set of circumstances under which safety improvements are desirable from a societal benefit-cost standpoint. But in all of the statistical tests using regression results, the level of the cost-perlife-saved did not have any significant effect on juror decisions to levy punitive damages or on the amount of the award. The fact that jurors are unresponsive to the cost-per-life-saved is consistent with the broader theme in the survey results: The key substantive concerns that one would expect to drive the jurors' views do not have a statistically significant influence.

The second set of scenarios-Scenarios 3 through 5 -consists of those in which the company performed a benefit-cost analysis of some kind. In Scenario 3 , the company valued each life in much the same manner as Ford and GM in cases discussed below: by using an amount comparable to the compensatory damages amount in similar cases. In particular, Scenario 3 stated that the company valued each life lost at $\$ 800,000$. In this scenario, as well as in Scenarios 4 and 5, the cost that the company would have had to incur to save a statistical life was $\$ 4$ million.

In Scenario 4, the company undertook the analysis in a manner that follows the approach taken by government regulatory agencies. Rather than use the compensatory damages amount, it used a value-of-life figure based on society's willingness to pay to prevent small risks of death. Consequently, this measure goes beyond the value of a person's earnings or the usual amount of a compensatory damage award. Rather, it reflects the risk-money tradeoff based on the individual's own willingness to pay for greater safety. This approach is favored for use throughout the federal government by the U.S. Office of Management and Budget. 15 As described in Scenario 4:

To determine whether the safety improvement was worthwhile, the company used a value of $\$ 3$ million per accidental death, which is the value used by the National Highway Traffic Safety Administration in setting auto safety standards. The company estimated that the annual safety benefits of this safer design would be $\$ 30$ million (10 expected deaths at $\$ 3$ million per death), while the cost would be $\$ 40$ million. As a result, the company believed that other safety improvements might save more lives at less cost.

By comparing the results for Scenario 4 with those in Scenario 3, we can ascertain whether undertaking the analysis in a rigorous and responsible economic fashion has any beneficial influence on how the jurors view a benefitcost analysis of product safety designs. Alternatively, comparing Scenario 4 with Scenario 1 makes it possible to ascertain whether performing an analysis helps or hurts the company's position in the eyes of the jury, holding constant the cost-per-life-saved value.

The final survey variant, in Scenario 5, is that in which the company makes a mistake in assessing the risk component, underestimating the num-

15. See U.S. OFFICE OF MANAGEMENT AND BUDGET, REgUlatoRy PROGRAM OF THE UNITED STATES GOVERNMENT 634 (1993). 
ber of deaths by a factor of two. Under this analysis, the company estimates that the cost-per-life-saved would be $\$ 4$ million, whereas in fact it is $\$ 2$ million. Since the reference value of life used by the National Highway Traffic Safety Administration is $\$ 3$ million per life, this error represents the difference between the analysis passing and failing a benefit-cost test. The company believed that it passed, but, because of the error, it did not. Comparison of the results in Scenario 5 with Scenario 4 enables us to determine whether such errors in a benefit-cost analysis affect juror attitudes toward corporate risk analysis.

The bottom rows in Tables 1 and 2 indicate the different waves of the survey. One set of respondents considered the set of five scenarios in which the total number of lives lost was ten. A second set of respondents considered identical scenarios, except that the total number of lives lost was four. The number of lives lost did not have any statistically significant influence on the responses. Thus, within the ranges examined, neither the cost-perlife-saved nor the absolute level of risk had any statistically significant influence on jurors' propensity to award punitive damages.

Table 3 reports the mean values of the jurors' reactions to the five scenarios, both in terms of their propensity to award punitive damages, and the dollar value they choose for such awards. The different versions of the survey are listed in the first column of Table 3. The table also presents each of the different scenarios and summarizes the results for the combined group of two scenarios in which no benefit-cost analysis was performed, the three scenarios in which there was such a benefit-cost analysis, and all five scenarios.

Consider first the frequency with which punitive damages were awarded. In Scenario 1 , the reference scenario in which the cost to save a life was $\$ 4$ million but no analysis was performed, $85 \%$ of these subjects were willing to award punitive damages. This figure rises to $92 \%$ for Scenario 2 in which no analysis is performed, but the cost to save a life drops to $\$ 1$ million.16 Overall, the two versions of the survey in which there is no analysis performed had $88 \%$ of the subjects awarding punitive damages. Because of this high base level, the incremental effect of the corporate analysis scenarios will largely be manifested in damage levels.

One would expect jurors to be more lenient if the company could justify its actions based on a benefit-cost analysis. The opposite turns out to be the case. In the three scenarios in which the company did perform a benefit-cost analysis using either compensatory damages amounts or the willingness to pay for safety measure for the value of life, the probability of awarding pu-

16. The percentages of jurors willing to award punitive damages in these scenarios are not, however, statistically different from each other, as indicated by the associated $t$ value of 1.58 . See infra app. tbl. 2. 
nitive damages ranged from 0.93 to 0.95 . These differences are not statistically significant across the different cases.17 Thus, the character of the analysis that the company performs does not have a statistically significant effect. There is, however, a statistically significant difference between Scenarios 3,4, and 5, in which a company does an analysis, and Scenarios 1 and 2 , in which it does not. Overall, the scenarios in which a company performed an analysis led to a punitive damages award $94 \%$ of the time. That value is $6 \%$ higher than the two cases for which no analysis was performed and $9 \%$ higher than in Scenario 1, in which no analysis was performed and the cost-per-life-saved was $\$ 4$ million per life. The variation in the frequency with which jurors award punitive damages is not great because these frequencies were very high in all of the scenarios. But the direction of the effect is disturbing, since the mock jurors were doing the opposite of what juries should do to encourage corporations to think systematically about risk and cost tradeoffs.

The magnitude of the awards displays considerably more variation. The last two columns in Table 3 present the geometric mean and the median award values. I present these statistics rather than the simple average award amount because a few outliers in which extremely large punitive damages were awarded-as high as $\$ 8$ billion per fatality-distort the average. There is a remarkable difference across the no-analysis and risk-analysis scenarios. For the two scenarios in which the company does not undertake a benefitcost analysis, the value of the awards is almost identical. The geometric mean value ranges from $\$ 2.86$ million to $\$ 2.95$ million, or an average across the two groups of $\$ 2.91$ million. The median value is identical for both Scenario 1 and Scenario 2, at $\$ 1$ million.

As indicated by the bottom rows of Panels A and B of Table 3, the award amount is roughly $50 \%$ greater in situations in which the company performed a benefit-cost analysis, as compared to the no-analysis scenarios. Overall, the scenarios in which an analysis was performed led to damages with a geometric mean value of $\$ 4.59$ million, as compared to $\$ 2.91$ million when no analysis was undertaken. The median values display a more dramatic pattern: They are $\$ 1$ million when no analysis is performed and $\$ 10$ million when the company does a benefit-cost analysis.

The company's performance changes when it undertakes a benefit-cost analysis correctly, as in Scenario 4, rather than simply using the value of compensatory damages as the measure for the value of life, as in Scenario 3. Based on the economic merits, the company should fare better when it values life correctly and at a higher amount than when it simply uses the compensatory damages value. Additionally, respondents are told that the company's approach follows that used by the National Highway Traffic Safety Admini-

17. In particular, the highest $t$ value is 0.545 . 
stration (NHTSA). But undertaking a sound risk analysis does not prove to be beneficial to the company's prospects. The propensity of the respondents to award punitive damages is almost identical -0.93 - in each case. But the level of punitive damages awarded turns out to be greater when the company performs the analysis correctly than when it simply uses the compensatory damages value. The geometric mean award value increases from $\$ 4.0$ million in Scenario 3 to $\$ 5.3$ million in Scenario 4. The median award value is $\$ 3.5$ million in Scenario 3, less than half the $\$ 10$ million median value for Scenario 4-a statistically significant difference. 18

Performing the analysis correctly and valuing life at a higher amount lead juries to impose greater sanctions than when the company does the analysis but places a lower value on improvements in safety. How might such a seemingly unreasonable pattern of behavior arise? The mock jurors seem to make little distinction with respect to whether there should be an award of punitive damages. But the higher value-of-life amount used by the company in Scenario 4 as compared to Scenario 3 provides a dollar anchor for the jury in determining the appropriate punitive damages award. Somewhat perversely, use of a higher value-of-life estimate in a company's internal analysis may raise the target award level in jurors' minds. This might be because they seek to impose damages that will provide a greater safety incentive for companies in similar situations as the company in their Scenario, in the hope that this incentive would lead similarly placed companies in the future to a different conclusion in their internal analyses. Consequently, companies are in the bizarre position of risking greater liability if they place more weight on consumer safety.

Anchoring effects for punitive damages are not unique to this context. Plaintiffs' attorneys' requests for larger damages tend to increase the dollar value of the awards. 19 Such requests are not entirely arbitrary because they are often accompanied by superficially plausible mathematical formulas, such as an arbitrary percentage of the firm's profits or sales, that are based on the purported need to send the company a message. Indeed, recent evidence indicates that, in fact, jurors may have very little idea how to map their concerns about the corporation's behavior into a dollar amount.20 My results are even more disturbing, because not only is there an anchoring phenomenon that is the opposite of the desired effect, but also because responsible risk analyses should not trigger punitive damages of any kind.

18. A median regression yields a $t$ value of 3.36. A regression using the geometric mean, however, does not yield a statistically significant $t$ value.

19. See generally Reid Hastie, David A. Schkade \& John W. Payne, Juror Judgements in Civil Cases: Hindsight Effects on Judgments of Liability for Punitive Damages, 23 LAW \& HuM. BEHAV. 597, 597-614 (1999) (providing detailed evidence of this phenomenon).

20. See Sunstein, Kahneman \& Schkade, supra note 12, at 2074 (arguing that jurors have trouble arriving at dollar amounts that are not arbitrary because they are asked to map moral judgments onto an unbounded scale of dollars). 
Finally, consider Scenario 5 , in which the company undertook a flawed benefit-cost analysis. Comparison with the counterpart Scenario 4, in which there was no such error, suggests that errors are not very consequential. The jury was somewhat more likely to award punitive damages in the erroneous analysis case ( 0.95 probability versus 0.93 ), but exhibited somewhat lower proclivities to penalize the firm ( $\$ 4.5$ million in punitive damages for Scenario 5 versus $\$ 5.3$ million for Scenario 4). Overall, there were no statistically significant differences between these two scenarios.

More detailed statistical analyses that control for variations in scenario features and respondent characteristics yield similar results.21 Taking into account the influence of mock jurors' personal characteristics, such as gender and education, undertaking a risk analysis increases the probability of a punitive damages award by $5 \%$. It is noteworthy that the cost-per-life-saved and the absolute risk level do not have significant effects on the probability of a punitive damages award: Mock-jurors seem unresponsive to variations in the underlying risk characteristics. Undertaking a benefit-cost analysis of risk does not help the company, but instead boosts the punitive damages awarded by $47 \%$. The cost-per-life-saved and the absolute risk level do not affect jury behavior significantly.

\section{THE RISK-BALANCING REFERENCE POINT}

\section{A. Risk Analysis and Liability}

What should the negligence standard be and what role should risk analysis play in relation to such a standard? The current legal consensus on this issue, articulated in a draft document by the American Law Institute, reflects a desire to balance risk and cost and, indeed, to consider risk-cost tradeoffs directly:

Under $\S 4$, negligence is defined in terms of the failure to exercise reasonable care, and reasonable care is explained primarily in terms of the balance between the magnitude of the foreseeable risk and the burden of precautions that can eliminate the risk. If the burden is greater than the risk, the actor who declines to adopt that precaution is not negligent. But if the magnitude of the risk is somewhat greater than the burden, the actor is negligent for failing to adopt the precaution.

From this evaluation, two points follow that relate to the meaning of recklessness. The first point is a negative one: the fact that the actor, because of the burden entailed by a particular precaution, has made a deliberate choice to omit a precaution and hence to tolerate a risk by no means signifies that the person has behaved recklessly. Indeed, the fact that such a choice has been made does 
not even show that the actor has behaved negligently. Rather, the actor is negligent only for making an unwise choice. In a sense, the very objective of negligence law is to encourage actors to acknowledge and confront such choices, and to render these choices wisely rather than unwisely. 22

Standard negligence principles call for risk balancing, and firms should be encouraged to make such judgments explicitly. Ideally, they should not be faulted additionally for undertaking an erroneous analysis. Undertaking a risk analysis before marketing a risky product should not be viewed as reckless corporate behavior. Such legal ideals are, however, divorced from the reality of personal injury and environmental damage cases and the thinking of jurors with cognitive biases. The injuries in such cases are more than financial abstractions: They often generate powerful emotional responses, which may be affected by the character of the corporate decisionmaking process, as will be shown below.

These competing concerns arise in the American Law Institute's discussion of the role of the actor's knowledge, which is an integral component of risk analysis: "Nevertheless, if the evidence does show that the actor had knowledge that its conduct was tortious, this evidence conduces to a finding that the actor's failure to adopt precautions is highly blameworthy for the purposes of $\S 2 .{ }^{\prime \prime 23}$ Companies, of course, may make risk analyses and adopt behavior that they do not regard as tortious. Juries may, however, disagree, and if the firm is found negligent then its risk analysis and cognizance of the risks posed by dangerous products could trigger punitive damages.

To provide levels of safety that protect the public adequately, companies should institute those safety measures for which the expected benefits exceed the costs. Cost levels are usually directly measurable; they typically consist of monetary expenditures and the time spent taking particular precautions. The benefit component is more complex. Consider a safety device that reduces mortality risks to consumers. For simplicity, assume that all of these calculations are undertaken on a per-consumer basis rather than over the entire product line, in which case one would take into account the total number of consumers whose lives are at risk and the total cost involved. The expected benefits of the safety device equal the change in the mortality probability multiplied by the value of preventing the consumer's death. The safety device is desirable from an economic efficiency standpoint if the costs are less than these expected benefits.

Assessing risk levels and how a product alters the risk is not always a precise science, particularly before the product is marketed. Engineers can run simulations, and pharmaceutical companies can engage in clinical trials that may involve substantial groups of prospective users in situations that

22. RESTATEMENT (THIRD) OF TORTS $\S 2 \mathrm{cmt}$. d (Council Draft No. 1, 1998).

23. $I d . \S 2 \mathrm{cmt}$. $\mathrm{g}$. 
reflect the likely product use. But such pre-market tests are often not fully informative. Adverse reactions to a drug may not become apparent immediately, and mechanical defects may develop over time and therefore not be known to the company before the product is marketed. Also, companies cannot anticipate all situations in which the product will be used. Nevertheless, there is often substantial information that the company can use to form a risk judgment. Using the information reasonably available at the time of the risk analysis, the company can assess the change in the fatality probability that would result from a particular safety improvement.

\section{B. Setting a Price on Safety}

Supreme Court Justice Stephen Breyer uses the example of consumer spending on auto safety to demonstrate our natural risk-money tradeoffs. ${ }^{24}$ Would it, for example, be unreasonable to require a safety expenditure that costs $\$ 10$ billion per life saved? As Justice Breyer observes, such expenditures would be tantamount to being willing to pay an extra $\$ 48,077$ for a car $5 \%$ safer than those we now drive. The fact that we do not all rush out to purchase marginally safer cars that are vastly more expensive reflects the limits we place on safety improvements. Indeed, the tradeoffs revealed by consumer purchases of used cars indicate that consumers are willing to pay approximately $\$ 3$ million for each statistical life saved by the decreased risk of death offered by the purchase of a safer used car. ${ }^{25}$

What Justice Breyer's example implies is that there will always be some product hazards that will not be corrected. The failure to obtain risk-free products will occur regardless of whether it is the consumer or the producer who makes the safety decision. At some point, the cost of additional safety improvements becomes so great that additional safety measures are not worthwhile.

Indeed, a desire to limit our expenditures on product safety could even stem from interest in other health-enhancing expenditures. Exorbitant expenditures on motor-vehicle safety, for example, would divert resources that could have been spent on additional medical care, improved nutrition, or housing in a safer neighborhood. A substantial literature has developed in economics demonstrating that excessive safety expenditures in any particular area are counterproductive. ${ }^{26}$ We harm our health by diverting inordinate

24. See BREYER, supra note 4, at 13-14.

25. See Mark K. Dreyfus \& W. Kip Viscusi, Rates of Time Preference and Consumer Valuations of Automobile Safety and Fuel Efficiency, 38 J.L. \& ECON. 79, 102 (1995) (finding implicit value of life estimates for automobile owners in the range of \$2.6 to \$3.7 million).

26. See generally W. KIP VISCUSI, RATIONAL RISK POLICY (1998) (providing an introduction to the risk-risk literature); Randall Lutter \& John F. Morrall III, Health-Health Analysis: $A$ New Way to Evaluate Health and Safety Regulation, 8 J. RISK \& UNCERTAINTY 43 (1994) (suggesting 
resources to one safety concern instead of allocating our funds across different ways of enhancing safety based on the relative efficacy of those expenditures.

In setting a dollar value on human life, economists focus not on identified lives, but on statistical lives. What matters is not how much we would pay to prevent a certain death. Rather, the actual benefit being valued is a prospective statistical death. There is some probability that this product will cause injury or environmental damage. How much are we willing to pay to reduce this often small probability by a tiny fraction?

A hypothetical example illustrates how the value-of-life numbers are generated. Consider a village with a population of 10,000 . Suppose that we learn that one person in the village will die at random. How much would the average person in the village be willing to contribute to prevent this random death (assuming that the villagers cannot leave or otherwise escape the risk)? If each person were willing to contribute $\$ 500$ to prevent a random death, they could raise $\$ 500$ multiplied by 10,000 people, or $\$ 5$ million. This same logic has been used to derive estimates based on a large series of studies of worker behavior, which has been the general approach taken in the economics literature. Studies focusing on tradeoffs people actually make between money and risk will consequently be more realistic than survey responses to hypothetical risks. Controlling for other aspects of the job, hazardous jobs command a higher price. For a worker facing an annual death risk of one chance in 10,000 from his or her job, the annual wage premium estimates range from $\$ 300-\$ 700$ per year, where these amounts control for other aspects of the individual and the job. Put in value-of-life terms, these amounts imply a value of life of $\$ 3$ million to $\$ 7$ million, or a midpoint value of $\$ 5$ million per statistical life.

These amounts do not imply that the worker would accept certain death in return for $\$ 5$ million, nor do they imply that a worker would be willing to pay $\$ 5$ million to prevent certain death. Those sums could be quite different. Rather, they only suggest that when facing very small risks, a value of $\$ 5$ million per statistical death reflects the person's rate of tradeoff between risk and money. For the purposes of the discussion below, this willingness-topay approach will be the yardstick used in assessing the value of life.

The use of this methodology to value life is not an arbitrary choice. It follows the recommended practice for all federal agencies. ${ }^{27}$ The justification for using the willingness-to-pay measure parallels the approach for valuing any policy's effects. The value of a policy benefit is simply soci-

that exceptionally costly health and safety regulations might worsen health and safety by reducing other spending on health and safety precautions).

27. See U.S. OFFICE OF MANAGEMENT AND BUDGET, supra note 15, at 633-38 (discussing the value of life). 
ety's willingness to pay for that benefit.28 In the risk context, it is the willingness to pay for risk reduction. Because the people whose lives are at risk have the most to lose, the usual reference point for valuing safety is the willingness of the person at risk to pay for safety.

The value-of-life numbers are considerably higher than the estimates obtained using only the present value of lost earnings, which is often called the "human capital" approach. Lost earnings are generally a key component of compensatory damages amounts. Ignoring the role of discounting, consider a thirty-five-year-old male earning $\$ 30,000$ per year. That person has an expected active working life of just under twenty-five years, or a total value of future earnings of $\$ 750,000$. $^{29}$ Whereas the value of future earnings is under $\$ 1$ million, the value of life arrived at through the willingness-to-pay measure is much higher.

When making awards in wrongful death cases, courts focus on the present value of future earnings, net of consumption of the deceased and, depending on the jurisdiction, taxes. That amount of money is needed to replace the economic loss to the family based on the earnings of the deceased. But compensatory damages awarded by courts in this manner do not serve the preventive function reflected in the value-of-life statistics. A value-oflife figure of $\$ 5$ million is an appropriate reference point for determining how much the company should spend per statistical life to prevent an expected death, even though a typical court award in the case of wrongful death may be less than $\$ 1$ million. This distinction was incorporated in the contrast between Scenarios 3 and 4, which demonstrated the perverse result that corporations were penalized for valuing life highly.

\section{Problems in Ex Post Jury Assessments of Risk Analyses}

Juries might not, in fact, compare expected benefits and costs based on the state of information before the accident. Once the accident has occurred, hindsight may taint juror perceptions. Instead of comparing expected benefits and costs, jurors may compare the enormous cost to the victim with the relatively negligible cost of the safety improvement.

The role of hindsight was apparent in Carroll $v$. Otis Elevator Co.30 In 1985, a department store escalator came to a sudden stop after an unidentified child apparently pushed the emergency button. Shirley Carroll, a department store clerk riding the escalator, fell and injured her knee. She filed a product liability suit against the escalator manufacturer, claiming that the

28. This is the standard principle for benefit valuation in any context. See generally, e.g., EDITH STOKEY \& RICHARD ZECKHAUSER, A PRIMER FOR POLICY ANALYSIS (1978).

29. These worklife statistics are from Table A-1 of BUREAU OF LABOR STATISTICS, U.S. DEP'T OF LABOR, WORKLIFE ESTMMATES: EFFECTS OF RACE AND EDUCATION 12 (1986).

30. 896 F.2d 210 (7th Cir. 1990). 
red emergency stop button was defective because it was attractive and accessible to children.31 In the defense's view, having a button that is easy to spot and reach enhances its role in emergency situations. ${ }^{32}$

As Judge Frank Easterbrook observed in his concurrence, corporate engineers are better suited to making sound risk tradeoffs than jurors, who are affected by hindsight bias:

The ex post perspective of litigation exerts a hydraulic force that distorts judgment. Engineers design escalators to minimize the sum of construction, operation, and injury costs. Department stores, which have nothing to gain from maiming their customers and employees, willingly pay for cost-effective precautions....

Come the lawsuit, however, the passenger injured by a stop presents himself as a person, not a probability. Jurors see today's injury; persons who would be injured if buttons were harder to find and use are invisible. Although witnesses may talk about them, they are spectral figures, insubstantial compared to the injured plaintiff, who appears in the flesh. ${ }^{33}$

Judge Easterbrook emphasized that companies should undertake riskcost balancing in a decision in a case involving burns from hot coffee that paralleled the highly publicized McDonald's coffee cup case. McMahon $v$. Bunn-O-Matic Corp. ${ }^{34}$ involved a coffee spill by the McMahons while on a long trip. Jack McMahon bought a cup of coffee in a Styrofoam cup at a Mobil station. As he poured his coffee into a smaller cup the original cup collapsed, spilling its contents on Angelina McMahon's lap and causing second and third-degree burns. The McMahons' suit against the manufacturer of the coffeemaker claimed that the maker was defective because the coffee was too hot.

Judge Easterbrook noted, however, that hot coffee might have more benefits than costs:

[B]ecause it is costly to serve coffee hot (it takes electricity to keep the hotplate on), risks could be reduced for a negative outlay. How can it not be negligent to spend money for the purpose of making a product more injurious? But of course people spend money to increase their risks all the time-they pay steep prices for ski vacations; they go to baseball games where flying bats and balls abound; they buy BB guns for their children knowing that the pellets can maim. They do these things because they perceive benefits from skiing, baseball, and target practice.... [W]e must understand the benefits of hot coffee in relation to its costs. As for costs, the record is silent. We do not know whether severe burns from coffee are frequent or rare. On the other side of the ledger there are benefits for all coffee drinkers. Jack McMahon testified that he likes his coffee hot. Why did the American National Standards Institute set $170^{\circ} \mathrm{F}$ as the minimum temperature at which coffee should be held ready to serve? ... With-

34. 150 F.3d 651 (7th Cir. 1998). 
out some way to compare the benefits of a design change (fewer and less severe burns) against the costs (less pleasure received from drinking coffee), it is impossible to say that designing a coffee maker to hold coffee at $179^{\circ} \mathrm{F}$ bespeaks negligent inattention to the risks. 35

As a practical matter, consider the process that a company might undertake if it wished to complete a comprehensive assessment of the costs and benefits of a particular safety improvement. It would obtain a thorough understanding of the risks involved and how the safety device would affect those risks. If it chose not to adopt a safety measure because the costs exceeded the benefits, then it would be explicitly trading off lives against money, just as coffee retailers and coffeemaker manufacturers trade off burns against quality and profits. Moreover, proceeding in a way that is not risk free would be to knowingly expose consumers to a probabilistic risk of harm, even though such actions may be entirely in line with fundamental law and economics principles for efficient levels of safety.

Unfortunately, knowingly inflicting a risk will trigger certain conditions that are highlighted for juries with respect to the award of punitive damages. Consider the following jury instructions for punitive damages pertaining to willful and wanton conduct:

In order for the conduct of the defendant to constitute willfulness or wantonness, his/her acts must be done under circumstances which show that he/she was aware from his/her knowledge of existing conditions that it is probable that injury would result from his/her acts and omissions, and nevertheless proceeded with reckless indifference as to the consequences and without care for the rights of others.

The distinction between the two terms, "willful" and "wanton," is that the word "willful" implies an intent or purpose to cause injury, while "wanton" expresses a reckless disregard for the consequences of the act.

It is not necessary to find that the defendant deliberately intended to injure the plaintiff. It is sufficient if the plaintiff proves by the greater weight of the evidence that the defendant intentionally acted in such a way that the natural and probable consequence of his act was injury to the plaintiff. 36

How will a jury interpret such instructions? Suppose the defendant undertook a thorough risk analysis, yet nevertheless proceeded with a product that did not incorporate all feasible safety measures because of their inordinate cost. Will a jury find that the defendant's conduct is reckless and caused an injury to the plaintiff because the defendant chose not to adopt the safety measure despite knowing of the adverse consequences? Punishing such responsible corporate risk analyses occurred not only in the mock juror results but also in the cases examined below.

35. Id. at 658. 1993).

36. RONALD W. EADES, JURY INSTRUCTIONS ON DAMAGES IN TORT ACTIONS 111 (3d ed. 


\section{Risk-Utility Analysis}

The procedure by which one compares the benefits of design changes with the associated costs is not restricted to corporate risk analyses or benefit-cost tests undertaken by the government with respect to prospective regulations. Such procedures also are embodied with respect to legal tests for design defects known as risk-utility tests. Such tests involve balancing a variety of the elements of benefit-cost analysis, but do not involve a formal benefit-cost test. ${ }^{37}$

Risk-utility tests of various kinds play a central role in design defect cases. ${ }^{38}$ Even if the focus is on consumer expectations, judgments as to whether reasonable expectations are met may hinge on risk-utility concerns. ${ }^{39}$ Although risk-utility analysis does have a legitimate legal role, this status does not protect companies that have undertaken such studies. Jurors are still free to punish corporations for thinking systematically about risk and cost.

Undertaking a sound analysis of the benefits and costs of safety improvements may be a recipe for being penalized by a jury. In undertaking such an analysis, a company will become aware of the linkage between a particular safety improvement and the probability of injury associated with foregoing that improvement. Moreover, undertaking such an analysis and making a conscious decision to forego the improvement will subject a company to the charge that it "deliberately intended to injure the plaintiff." In the view of the plaintiff's attorneys, a company would only do so for the basest of reasons-financial gain.

Economic analysis of potential safety improvements and environmental precautions is inherently unpleasant and may offend jurors. Tradeoffs will and must be made. The unpleasant nature of the exercise does not, however, imply that companies should not undertake such assessments. Indeed, rational thinking about risks is exactly what we want to encourage. Such rational thinking leads to warranted safety improvements, rather than other safety measures that raise product price but confer negligible gains. As case studies discussed below indicate, however, undertaking even a sound assessment of costs and benefits often poses substantial hazards to responsible corporations.

37. See W. KIP VISCUSI, REFORMING PRODUCTS LIABILITY 65-86 (1991); Wade, supra note 4, at 837-38 (offering a list of factors to weigh when determining whether a product is "unreasonably dangerous").

38. See RESTATEMENT (THIRD) OF TORTS: PRODUCTS LIABILITY § 2D (Council Draft No. 1, 1998) (noting that case law in some jurisdictions asserts that defective design is to be determined by risk-utility balancing, which involves balancing the likelihood and magnitude of foreseeable harm against the burden of the precaution).

39. See id. $\S 2 \mathrm{C}$. 


\section{E. Risk Analysis After Accidents}

Risk analyses are certainly valuable for fostering safe product designs. They are also valuable after accidents as companies attempt to diagnose the causes of accidents in efforts to improve their safety records. A prominent class of examples consists of airplane crashes. Indeed, the 1979 American Airlines DC-10 crash at O'Hare Airport led to a legal battle over what corporate records had to be shared with the plaintiffs. 40 A key issue that American Airlines lost was whether it had to provide the plaintiffs with the results of its crash investigation. American Airlines had investigated the causes of the crash but later destroyed the resulting report on the advice of its counsel. American Airlines' counsel claimed that the report was covered by attorneyclient privilege. The airline's legal department also instructed the accident investigators to destroy all supporting notes and copies of the report. The plaintiffs claimed that this action increased their costs, and the court ruled in favor of their claim. By not preserving the report, American Airlines led the court to conclude that the contents of the report would have been damaging: "The 'adverse inference' rule does apply to this motion, however. That rule basically holds that upon a party's willful failure to produce evidence, there is the presumption that the evidence would have been unfavorable to that party." 41

From the standpoint of efficient risk analysis, what should the objective of the post-crash analysis be? Ideally, it should focus on the causes of the crash and reasonable potential measures that may reduce such risks in the future. The analysis should highlight shortcomings that can be fixed to prevent future tragedies. The effect of such a frank assessment, however, could be to increase the company's liability.

From the standpoint of risk analysis and recordkeeping objectives, companies face a complex Catch 22 situation. 42 If they undertake no postaccident risk evaluation, they might be found irresponsible for failing to address the risks that caused the accident. Investigating the cause of a major accident will be a signal to the jury that the company was concerned for safety, because learning what caused an accident is often a key ingredient in preventing recurrences. But a frank post-accident report that is shared with the plaintiffs could affect the company's liability for the accident if the report finds fault with the company practices that led to the accident. If, however, the company fails to maintain or produce such accident reports, it may be

40. See In re Air Crash Disaster Near Chicago, Illinois on May 25, 1979, 90 F.R.D. 613 (N.D. Ill. 1981).

41. Id. at 621. For a fuller discussion of this case, see Donald S. Skupsky, Legal Requirements for Records Prepared for Internal Investigations and Audits, REC. MGMT. Q., Apr. 1992, at 34.

42. The three unattractive alternatives specified below are based on the analysis by Skupsky, supra note 41 , at 36 . 
subject to litigation for not fulfilling its obligation to learn about product hazards and provide reasonably safe products. From a societal standpoint, there is a desire both to make the appropriate liability decision for the current accident and to provide incentives for the corporation to adopt appropriate safety measures in the future.

The sections below consider a variety of concrete cases in which corporate risk analyses have played a role in court. In most of these examples companies were found liable, often for punitive damages. These examples are not disturbing because the act of carrying out a risk analysis did not shelter the firm from liability: I am not proposing that doing a risk analysis immunizes the company against all subsequent liability. But undertaking a systematic risk analysis should not itself be a trigger for imposing liability. Moreover, if the analysis is sound and indicates that the costs of a safety measure exceed the value of the safety benefits it produces, then the firm is not negligent for foregoing the measure. In such cases, the firm should escape not only punitive damages, but liability altogether.

In some corporate risk analyses, the analysis may not be economically sound. In such cases, some liability may be warranted. But technical shortcomings in the analysis are not apparent matters of concern in the cases discussed below. What the attorneys and the jurors reacted to was the fact that the company had undertaken the analysis, had specifically confronted the risk decision, and had chosen not to adopt every feasible safety measure. Whether doing so would have been sensible given the state of information before the accident never enters as an explicit concern. The practical danger is that jurors react in hindsight, comparing the cost of the product design change with the costs to the identified victim, as Judge Easterbrook suggested.43 The result is that jurors place insufficient weight on the fact that adverse outcomes often have very low probabilities. The company must make a product-wide decision; and cannot identify in advance the potentially injured parties and craft only those safety improvements that will affect them.

\section{BENEFIT-COST ANALYSES AT FORD MOTOR COMPANY}

\section{A. The Ford Pinto}

A useful starting point for considering the role of corporate risk analysis is the Ford Pinto case, Grimshaw v. Ford Motor Co.44 Although the incident occurred a quarter century ago, it remains perhaps the best-known example

44. 174 Cal. Rptr. 348 (Cal. Ct. App. 1981). 
of a corporate risk analysis provoking public outcry. Moreover, this classic case embodies many key elements that appear in other cases.

Grimshaw v. Ford Motor Co. involved the rear impact of a Ford Pinto. In 1972, Richard Grimshaw was a thirteen-year-old passenger in a Ford Pinto that had stalled and come to a stop in the middle of a freeway. A car that had slowed to approximately thirty miles per hour hit the Pinto from behind, causing a fire that killed the driver and catastrophically injured Grimshaw. 45

The plaintiff's suit claimed that the placement of the gas tank behind the rear axle and the design of the fuel filler pipe were defective designs that created the risk of fire. Grimshaw was awarded more than $\$ 2.5$ million in compensatory damages and $\$ 125$ million in punitive damages. 46 The punitive award was subsequently reduced to $\$ 3.5$ million. ${ }^{47}$

The most publicized aspect of the Ford Pinto experience was a systematic analysis of the benefits and costs of safety improvements. Mother Jones magazine published the analysis, ${ }^{48}$ which trial lawyer Stuart Speiser called "possibly the most remarkable document ever produced in an American lawsuit ....,49 At a press conference, Mother Jones and Ralph Nader released the analysis. Its story documenting this benefit-cost analysis by Ford engineers received a Pulitzer Prize. ${ }^{50}$ While the Ford Pinto case dealt with a rear impact, the engineering analysis undertaken by Ford pertained not to rear impact crashes but to rollover risks and a regulation that had been proposed by the NHTSA. ${ }^{51}$ Nevertheless, the analysis demonstrates how corporate engineers undertake safety studies. Moreover, this same kind of analysis has been the subject of other Ford and General Motors risk assessments.

Table 4 highlights the components of the Ford Pinto benefit-cost analysis. The character of the risks was estimated using data from a broader car population. Panel A lists potential injuries and Ford engineers' unit estimates of the values for these injuries. ${ }^{52}$ Ford estimated potential risks as 180

45. See id. at 359.

46. See id. at 358 .

47. See generally Gary T. Schwartz, The Myth of the Ford Pinto Case, 43 RUTGERS L. REV. 1013 (1991) (describing the public debate and misconceptions surrounding the case).

48. See Mark Dowie, Pinto Madness, MOTHER JONES, Sept.-Oct. 1977, at 2.

49. STUART M. SPEISER, LAWSUIT 357 (1980).

50. For a discussion of these events, see Schwartz, supra note 47, at 1017.

51. See id. at 1020-21.

52. For a synopsis of the memorandum, see BRENT FISSE \& JOHN BRAITHWAITE, THE IMPACT OF PUBLICITY ON CORPORATE OFFENDERS 44 (1983). As Fisse and Braithwaite observed:

In the absence of an offense defined in terms of manufacturing an unjustifiably dangerous product, questions of acceptable risk of the kind raised by the Pinto Papers will rarely be the central subject of inquiry in the context of corporate offenses against the person. This is unsatisfactory, not only because of the danger of a serious underlying risk being concealed from society, but also because it may do more harm than good not to face up to the need for 
burn deaths, 180 serious burn injuries, and 2100 burned vehicles. The unit values applied to these injuries were similar to the value of court awards in product liability cases at that time, ${ }^{53}$ as well as to the values used by the NHTSA in its regulatory analyses. ${ }^{54}$ Each of these values was based on estimates of the present value of lost earnings. ${ }^{55}$ Based on Ford's analysis, the total cost of not fixing the gas tank design would be $\$ 49.6$ million. In contrast, as indicated in Panel B, the cost of increased safety would be $\$ 137.5$ million. By this tally, the expected benefits from improved safety were smaller than the costs; consequently, undertaking the design change was not worthwhile.

Based on current economic knowledge in the value-of-life area-as opposed to the state of economic knowledge a quarter century ago-we know that a different kind of analysis would have been appropriate. 56 In terms of the mock-juror survey, Ford followed the compensatory damages method for determining the value of life in Scenario 3 rather than the willingness-to-pay method in Scenario 4. But as the mock-juror survey indicates, following Scenario 4 rather than Scenario 3 would probably have affected Ford adversely to the extent that the higher willingness-to-pay value anchors damages at a higher level.

The basic problem is that jurors do not undertake a comprehensive risk analysis approach, regardless of its character. Jurors have a tendency to compare the often very small per-unit safety cost with the costs borne by the injured victim. Rather than examine the entire market and the associated benefits and costs, jurors will be offended by, or will not fully understand, a comprehensive risk-analysis approach and will focus their assessment more narrowly on the identified victim and the costs of preventing that injury. The fact that these costs would also have been incurred for thousands of consumers who were not injured will not loom as large, as Judge Easterbrook emphasized. Thus, there is a tendency to exhibit "hindsight bias" rather than to

studies of the costs of improving product safety in matters such as that in which Ford was pilloried.

Id. at 54 .

53. See VISCUSI, supra note 37, at 111.

54. See Schwartz, supra note 47 , at 1023-24.

55. Since that time, governmental risk analyses have shifted to an approach based on the value of a statistical life or the willingness to pay to avoid a statistical death as described above. See U.S. OFFICE OF MANAGEMENT AND BUDGET, supra note 15, at 633-35; W. KIP VISCUSI, FATAL TRADEOFFS: PUBLIC AND PRIVATE RESPONSIBILITIES FOR RISK 31 (1992) ("Indeed, the value-of-life approach is now required by the U.S. Office of Management and Budget as a standard practice for all new major federal regulations.").

56. If Ford had used today's value-of-life estimates based on the willingness to pay to reduce risk, then the value of burn deaths would have been much greater. Using a value-of-life estimate of $\$ 3$ million per death, for example, preventing the burn deaths alone is worth $\$ 540$ million, which exceeds the total costs of eliminating the risk. 
consider the expected costs and expected benefits at the time of the safety decision.

\section{B. Ford Mustang}

A similar kind of risk analysis issue, or what the court viewed as "safety science management," arose with respect to the placement and design of the fuel system for the Ford Mustang in Ford Motor Co. v. Stubblefield. ${ }^{57}$ The issues raised in this case closely parallel those involved in the Ford Pinto case. In 1977, Terri Stubblefield was riding in the rear seat of a Ford Mustang II when it was hit from behind while stopped in traffic by a car that was traveling at approximately sixty miles per hour. The collision caused a "ball of fire" that engulfed the rear seat and killed Stubblefield. 58

The plaintiffs claimed that the fuel system was negligently designed and placed. Stubblefield's parents based their case on the company's prior knowledge of the risk, which is the kind of knowledge that is an integral part of any risk analysis. As a result, the jury awarded $\$ 8$ million in punitive damages to deter Ford Motor Company from such conduct in the future. Indeed, the award was based in large part on the fact that Ford had done a risk assessment that compared risk with cost and concluded that the safety improvements were not worthwhile:

The evidence here was sufficient to authorize the jury to find that the sum of $\$ 8$ million was an amount necessary to deter Ford from repeating its conduct; that is, its conscious decision to defer implementation of safety devices in order to protect its profits. One internal memo estimated that "the total financial effect of the Fuel System Integrity program [would] reduce Company profits over the 1973-1976 cycle by \$(109) million," and recommended that Ford "defer adoption of the [safety measures] on all affected cars until 1976 to realize a design cost savings of $\$ 20.9$ million compared to 1974." Another Ford document referred to a \$2 million cost differential as "marginal." 59

The design debate focused on the fuel system for the Ford Mustang II. The subject of the controversy was management's decision to delay implementation of protective hardware for the Mustang II fuel tank from 1974 until 1976. The design issues closely parallel those with the Ford Pinto: There was a possibility that rear-impact crashes would jam the fuel tank into the rear axle, generating the risk of a fuel-fed fire. As in the Fort Pinto case, the company's explicit tradeoff of cost for risk became the center of the controversy. Ford engineers recognized the hazard of post-crash, fuel-fed automobile fires and sought guidance on how to proceed from management. Ford executives decided to delay adoption of any protective device until 1976 in

57. 319 S.E.2d 470, 475 (Ga. Ct. App. 1984).

58. See id. at 474.

59. Id. at 481. Note that from an economic standpoint "marginal" often means "incremental" rather than "small." 
order to realize design cost savings of $\$ 20.9$ million. It was not until the fall of 1976 that Ford adopted a protective polyethylene shield. At no time did Ford warn consumers of the dangers of post-collision fire in the older models of the Mustang 11.60

The plaintiffs' allegations were two-fold. First, the alleged that the company traded off cost versus risk and knowingly inflicted harm on potential occupants. Crash tests analyzed in the course of the company's risk analysis "showed Ford's knowledge of the hazard at a point in time prior to the collision in which Stubblefield was fatally injured."61 Second, they alleged that because Ford knew about the potential risk, it had a duty to warn potential users of the hazard. The scope of any such duty to warn is unclear; not all products that are not completely risk free are required to carry warnings. Communicating very small probability risks is quite difficult, particularly given the myriad potential hazards associated with complex products like automobiles. It certainly would not be an effective hazard warnings policy for an automobile company to warn of every potential hazard associated with the product because doing so would cause problems of information overload.

\section{Ford's Seatbelt Failures}

Risk analysis became an issue for Ford again in another case, Miles $v$. Ford Motor Co.62 In the case, a jury awarded punitive damages-which were subsequently overturned-after the plaintiff sued Ford because the passenger-side shoulder harness on a seatbelt allegedly failed. Before the collision, Willie Miles, who was riding on the passenger side, had leaned over to pick up some trash. When doing so, the shoulder harness spooled out, creating slack of about six to eight inches. A "tension eliminator" apparently prevented appropriate rewinding of the belt even though the belt appeared to be snug. In the collision, the shoulder harness' failure caused Miles to slide through his lap belt, which caught his head and produced spinal injuries.

The basis of the claim was that the seatbelt's tension eliminator spool was defective, leading the occupant to believe that the shoulder harness was snug when in fact it was loose. The jury found that the design was defective and that the manufacturer had failed to provide adequate warnings regarding the defective restraint. Moreover, the company's risk analysis and the knowledge of the hazard incorporated in this analysis played a substantial role in the plaintiff's case:

Syson [the plaintiff's accident reconstruction expert] testified that he was familiar, during the relevant time period, with the corporate policies of Ford

60. See id. at 476 .

61. Id. at 479.

62. 922 S.W.2d 572 (Tex. App. 1996), remanded for procedural errors, Ford Motor Co. v. Miles, 967 S.W.2d 377 (Tex. 1998). 
Motor Company as they related to potentially defective products. Syson testified that when Ford identified what it believed was a defective product it would first run a "cost benefit" analysis to see what the cost would be to fix or repair the defect. Next, Ford would assign arbitrary values to each death or serious injury and would predict the number of occurrences which would involve either death or serious injury. Finally, Ford would determine the cost to litigate such deaths and injuries. Syson testified that if the cost to repair the defect exceeded the other costs, Ford would not correct the defect. 63

Notwithstanding the fact that the company undertook such an economic analysis, the court reversed the punitive damages award. Ford was fortunate in that its analysis was based on a regulatory analysis similar to the one undertaken by the NHTSA. As a result, the court concluded that the evidence was "barely sufficient to find ordinary negligence" and fell "far short of supporting a finding of gross negligence," much less malice.64 As the court noted: "Ford relied on studies by NHTSA that consistently showed the riskutility balance of tension eliminators weighed in favor of overall safety, and that the kind of tension eliminators Ford used were not unreasonably dangerous."65 Thus, the court stated, "[W] hile Ford's decision to use the tension eliminators may have turned out to be a mistake (ordinary negligence), it certainly cannot be said to have been a decision in conscious indifference to the safety of its customers or in spite of a known extreme risk or harm."66

Being vindicated by an explicit government regulatory risk assessment is the exception rather than the norm. As in Scenario 4, the jury was not swayed by a risk analysis that followed the guidelines used by the responsible federal regulatory agency, but instead penalized the firm with punitive damages. Upon appeal, the court overturned the jury's irrational punitive damages award. This appeal was aided by the fact it was the NHTSA studies themselves that, in effect, constituted the risk analysis. Had Ford instead relied on its own studies-but still used the NHTSA methodology, as in Scenario 4-the outcome might have been much less favorable.

\section{PRODUCT-RISK ANALYSES AT GENERAL MOtORS}

General Motors faced a fuel tank issue analogous to that in the Ford Pinto case in two cases. The first was a 1998 Georgia case, Moseley v. General Motors Corp., 67 which involved a side saddle fuel tank design that had been the target of numerous other lawsuits. 68 In this particular case, Moseley

63. Miles v. Ford Motor Co., 922 S.W.2d at 588-89.

64. Id. at 589.

65. Id.

66. Id. at 590.

67. Moseley v. General Motors Corp., 447 S.E.2d 302 (Ga. Ct. App. 1994), rev'd, Webster v. Boyett, 496 S.E.2d 459 (Ga. 1998).

68. See Moseley, 477 S.E. $2 \mathrm{~d}$ at 306. 
was driving a GM pickup truck that was hit broadside by a drunk driver of another pickup truck. Moseley survived the crash and suffered no internal injuries, but the gas tank ruptured and the truck caught fire, and Moseley was burned alive after impact. The jury concluded that the product defect pertained not simply to the placement of the fuel tanks, but also to the straps that bound the tank to the car and could potentially puncture the tank. 69

In terms of the overall risk posed by this particular truck design, GM trucks did not fare much worse than Ford trucks: The GM trucks had 1.51 deaths per 10,000 crashes, as compared to 1.45 deaths per 10,000 crashes for Ford.70 GM's extensive testing of the fuel tank system was the object of the litigation. The truck exceeded NHTSA standards by a substantial degree: From a regulatory standpoint, the truck design was not inadequate. But a key witness in the case presented the detailed GM analysis of fuel-fed fires and the costs of eliminating them, making "they knew" the "constant refrain among the jurors interviewed." 71 The jury awarded the plaintiffs $\$ 4$ million in compensatory damages, $\$ 1$ in pain and suffering, and $\$ 101$ million in punitive damages. To calculate the punitive damages amount, the jurors engaged in an arbitrary mathematical exercise. They awarded an amount equal to twenty dollars for each of the 500,000 GM trucks on the road, and added a bonus $\$ 1$ million "exclamation point." 72

The tank placement did have a constructive purpose in the vehicle design. GM wanted the truck to have a large fuel capacity so that drivers would not need to refuel the trucks frequently. Achieving this objective required the use of two tanks located outside of the frame rails that comprise the underbody of the truck.

In a 1973 analysis, GM engineer Edward Ivey prepared a benefit-cost analysis of the fuel fed fire fatality issue. 73 It is instructive to review this analysis in detail. Consider first his calculation of the health costs associated with fuel fed fires. Based on Ivey's "value analysis," there would be a maximum of "500 fatalities per year in accidents with fuel fed fires where the bodies were burnt." 74 He assigned each fatality a value of $\$ 200,000$, thus following the same approach taken in the Ford Pinto analysis. Multiplying five hundred fatalities by the value of $\$ 200,000$ each, and dividing by the forty-one million GM automobiles currently on the highways, yielded an estimated fatality cost of approximately $\$ 2.40$ per automobile. He then

69. See id. at 311-12.

70. See Terence Moran, GM Burns Itself, AM. LAw., Apr. 1993, at 68, 83 (describing the trial strategies, proceedings, and deliberations in Moseley).

71. Id. at 69.

72. Id.

73. Memorandum from E.C. Ivey, Value Analysis of Auto Fuel Fed Fire Related Fatalities, General Motors (June 29, 1973) (on file with the Stanford Law Review).

74. Id. at 2. 
amended this calculation to focus on new models sold during the current model year, for which he estimated fifty-five fatalities for the five million new models, leading to an estimated accident cost of $\$ 2.20$ per new-model automobile.

He concluded:

This analysis indicates that for G.M. it would be worth approximately $\$ 2.20$ per new model auto to prevent a fuel fed fire in all accidents... . This analysis must be tempered with two thoughts. First, it is really impossible to put a value on human life. This analysis tried to do so in an objective manner but a human fatality is really beyond value, subjectively. Secondly, it is impossible to design an automobile where fuel fed fires can be prevented in all accidents unless the automobile has a non-flammable fuel. .5

It is noteworthy that this analysis pertains to fuel fed fires more generally, and not to those in the specific target population of vehicles that was the object of the litigation. It is likely that the risks will be quite different for trucks with side saddle fuel tanks rather than the entire fleet of motor vehicles sold by GM. Consequently, the Ivey memo is not directly pertinent to the specific aspects of the Moseley case, except insofar as the memo indicated the character of corporate thinking. As in the case of the Ford Pinto analysis, the $\$ 200,000$ value per fatality uses a compensatory damages measure of the value of life, which was the approach used by NHTSA at that time. This amount is smaller than the willingness-to-pay measure of the value of life developed later in the economics literature. ${ }^{76}$

The GM approach was consistent with state-of-the-art research on valueof-life estimates at that time. Just as companies should be judged against the state-of-the-art with respect to scientific knowledge pertaining to safety designs rather than the state of future knowledge, they should not be expected to have applied methods of analysis that had not been developed by economic literature until after the corporate decisions in question were made. In the 1970s the dominant approach to measuring the value of life was the human capital method, which focused on the present value of the lost earnings of the deceased. This was, for example, the basis for the government's approach with respect to traffic safety. ${ }^{77}$ Indeed, the first estimates of the value of life from a prevention standpoint using the appropriate concept of the

75. Id.

76. For instance, using data from the early 1970 s, the estimated willingness to pay measure of the value of life is $\$ 3$ million in more recent dollars, or \$1 million in 1969 dollars. See W. KIP VISCUSI, EMPLOYMENT HAZARDS: AN INVESTIGATION OF MARKET PERFORMANCE 263 (1979) (examining the health and safety risks associated with employment and the method by which workers attach implicit dollar values to the possibilities of death and injury).

77. See Schwartz, supra note 47, at 1025-26. Articulation of this approach in the literature appears in Dorothy P. Rice \& Barbara S. Cooper, The Economic Value of Life, 57 AM. J. PUB. HEALTH 1954 (1967). 
value of a statistical life did not occur until later in the 1970s. ${ }^{78}$ Federal agencies did not use this concept until 1982, after a debate between the Occupational Safety and Health Administration (OSHA) and the U.S. Office of Management and Budget over the merits of the proposed hazardous communication regulation, ${ }^{79}$ which was appealed to then-Vice President Bush. Based on OSHA's analysis using human capital assessments, which he termed the "costs of death," the costs of the regulations exceeded the benefits. Using the willingness-to-pay measure of the value of life, however, the benefits exceeded the costs. ${ }^{80}$ For all contemporary benefit-cost analyses, one would expect the value-of-life measure to reflect the willingness-to-pay value, as in Scenario 4.

The Ivey memo played a pivotal role in the July 9, 1999 Los Angeles jury verdict against GM in a case involving a rear-end crash, which involved a rear-end crash into a 1979 Chevrolet Malibu. ${ }^{81}$ The record-setting verdict consisted of $\$ 107.8$ million in compensatory damages for the six burn victims as well as $\$ 4.8$ billion in punitive damages. Many observers speculated that the 1997 and 1998 landmark cigarette settlements of the state attorneys general lawsuits provided an anchor that led the jury to think in terms of billions of dollars rather than millions. 82

The basic facts of the case are similar to those of many other burn injury cases. On Christmas Eve in 1993, Patricia Anderson was driving home from church with her four children and a friend of the family. After slowing to stop for a red light, her Chevrolet Malibu was hit from the rear by a drunk driver believed to be going fifty miles per hour by the plaintiffs and seventy miles per hour by the defendant. The ensuing fire in the Malibu caused severe burn injuries to the passengers, including some disfigurement.

78. See, e.g., VISCUSI, supra note 76, at 241-63 (finding that a sample of 496 blue-collar workers put an implicit value on life of approximately \$1 million in 1969 dollars); Robert S. Smith, The Feasibility of an "Injury Tax" Approach to Occupational Safety, 38 LAW \& CONTEMP. PROBS. 730 (1974) (examining the feasibility of a public policy approach to occupational safety and health under which the government would levy a monetary penalty on firms for each case of work injury or disease); Richard Thaler \& Sherwin Rosen, The Value of Saving a Life: Evidence from the Labor Market, in HOUSEHOLD PRODUCTION AND CONSUMPTION 265 (Nestor E. Terleckyj ed., 1975) (examining and proposing methods for estimating the value of life using an individual's own willingness to pay for increased safety).

79. The hazard communication regulation "would have required labeling and other forms of risk communication for all risky chemicals used in manufacturing." See VISCUSI, supra note 55, at 262.

80. See id. The analysis that led to the adoption of the value-of-life principles in the federal government is in W. Kip Viscusi, Analysis of OMB and OSHA Evaluations of the Hazardous Communication Proposal, report prepared for Secretary of Labor Raymond Donovan (March 15, 1982) (on file with author).

81. See Pollack, Jury Verdict, supra note 1, at A8.

82. See O'Neill, Weinstein \& Malnic, supra note 2, at Al; Frank Swoboda \& Caroline E. Mayer, A $\$ 4.9$ Billion Message: Jury Hits GM with Historic Crash Verdict, WASH. POST, July 10, 1999 , at Al. 
Once again the Ivey memo played a prominent role in the courtroom battle even though GM maintained that the memo did not contribute to the vehicle's design. ${ }^{83}$ The cost of a safer design that could have prevented the injury by moving the gas tank twenty inches away from the rear bumper rather than eleven inches was $\$ 8.59$ per vehicle, according to evidence presented by the plaintiffs. ${ }^{84}$ The Ivey memo loomed particularly large as the plaintiff's attorney claimed that it showed that GM was "caught red handed."85 According to Ivey's analysis, the cost to the company of fuel tank fires was $\$ 2.40$ per vehicle. Linking the memo with the $\$ 8.59$ figure, which Ivey did not do, implied that the costs of safety to the company outweighed the benefits.

The plaintiff's lawyers demonized the GM decision as the result of an immoral calculation. As one of the lawyers observed after the trial, "The jurors wanted to send a message to General Motors that human life is more important than profits." "86 After the trial, jurors highlighted this tradeoff: "Jurors told reporters that they felt the company had valued life too lightly. 'We're just like numbers, I feel, to them,' one juror, Carl Vangelisti, told Reuters. 'Statistics. That's something that is wrong."'87

By their very nature risk analyses convert life and death issues into statistics. Moreover, benefit-cost tests intrinsically involve cost-health tradeoffs that some may find shocking. One juror reflected a zero-risk mentality rather than a more rational risk tradeoff mentality in her comment: "There was no evidence that the car they put out there was as safe as what they could have put out there."s8 But making such tradeoffs is inevitable. The task for the courts and society is to overcome the kinds of biases shown in the experimental results and vividly evidenced in the GM case.

Jurors' reckless disregard for rationality is reflected in their justification for the $\$ 4.8$ billion punitive damages award. The jurors selected that figure by linking it to General Motors' advertising expenses over a long period. ${ }^{89}$ Linking damages to advertising expenses is entirely arbitrary. The amount was also "two-thirds more than GM's entire profit for 1998,"90 which is a benchmark that shows the award magnitude, but is also unrelated to safety decisions for 1979 Chevrolet Malibus. This kind of voodoo economics

83. See Pollack, Jury Verdict, supra note 1, at A8; Jeffrey Ball \& Milo Geyelin, GM Ordered by Jury to Pay \$4.9 Billion, WALL ST. J., July 12, 1999, at A3.

84. See Pollack, Jury Verdict, supra note 1, at A8.

85. Jury Awards \$4.9 Billion to Crash Victims, Finds GM Bargained Away Passenger Safety, BNA PROD. SAFETY \& LIAB. REP., July 16, 1999, at 721.

86. Pollack, Jury Verdict, supra note 1, at A8.

87. Id.

88. See Ball \& Geyelin, supra note 83.

89. See Michael White, Jury Orders GM to Pay $\$ 4.9$ Billion, CHI. TRIB., July 10, 1999, at 1.

90. Swoboda \& Mayer, supra note 82. 
which the jury viewed as a sound basis for decisions contrasts with the much more reasoned balancing in the Ivey memo. As the Washington Post observed, such punitive damages awards "send a message to the public at large that the courts are more like a casino than a hall of justice."91

Undertaking at least part of a benefit-cost analysis and making some judgments regarding the desirability of safety measures is not unique to these specific cases. For example, the plaintiffs in another case focused on allegedly faulty door latches in the Chevrolet Blazer. The plaintiffs claimed that GM estimated a $\$ 216$ million parts cost and a $\$ 700$ million labor cost if a recall was initiated, for a total amount of $\$ 916$ million.92 Evidence of an internal timeline of GM's cost analysis, which indicated that GM knew of the safety latch problem and what it would cost to fix it, contributed to a $\$ 150$ million damage award, of which $\$ 100$ million was for punitive damages, in the case of a man paralyzed after his Blazer crashed.93 Indeed, even more fundamental efforts by the company to learn about its products' dangers, such as crash test results and video tapes of those crash tests, can and have been used against it in litigation. 94

These and other cases show that courts split on how to treat defendants' knowledge of safety issues. Courts should uniformly incorporate benefitcost analysis, risk-utility tests, and balancing efforts into negligence standards. This is the goal of our legal system and regulatory oversight efforts. In practice, however, undertaking a thorough analysis of the risks, comparing the risk costs and benefits, and then, in accordance with the result of the risk analysis, proceeding not to undertake the most vigilant safety measures identified may severely damage a company if jurors regard this knowledge as grounds for punitive damages.

This review of cases indicates that juries often regard corporate risk analyses as red flags. Rather than indicating concern with appropriate safety levels, such risk assessments may be viewed as an indication of callous disregard for human health. The evidence in the case analyses is consequently quite consistent with the mock juror evidence. 95

91. Casino Justice, WASH. POST, July 13, 1999, at A18.

92. See J. Stratton Shartel, Defense Timeline Plays Key Role in Trial Against GM, INSIDE LIT., July 1996, at $1,3$.

93. See Hardy v. General Motors Corp., No. CV-93-56 (Cir. Ct. Lowndes Co. Ala., June 3, 1996), which is discussed in detail in Shartel, supra note 92, at 1-4.

94. See Misener v. General Motors, 165 F.R.D. 105, 106-08 (D. Utah 1996) (holding that videotape and data from manufacturers' crash tests were admissible to demonstrate seat belt's defect and manufacturer's notice thereof).

95. The controlled experimental case scenarios offered the additional advantage of isolating the incremental influence of particular aspects of the case, such as the type of risk analysis performed. 


\section{PHARMACEUTICALS-RISK ANALYSIS WITH GOVERNMENT SUPERVISION}

The automobile industry case studies for the most part consisted of risk analyses undertaken independently by the automobile companies. Although jurors might be able to find flaws in those studies, if such studies are approved by a government agency and adhere to strict guidelines then matters should be quite different. Corporations presumably should never be subject to punitive damages for products passing a governmental risk analysis. The pharmaceutical industry provides a valuable case study in this regard because its products are subject to extremely stringent regulation by the Food and Drug Administration (FDA). In particular, all new drugs must meet rigid standards for safety and efficacy and appropriate risk-balancing criteria before the agency approves them.

Before a company can market a prescription drug, it must first obtain FDA approval. As part of this approval process, the applicant must provide substantial pre-marketing safety information based on human clinical trials. The first stage of this process typically involves the submission of an application to conduct clinical trials to investigate a new drug. The application must be submitted with information on the drug's chemistry, pharmacology, and the results of animal toxicology tests.96 These trials may then begin, provided the FDA does not either request more information or modify the protocol submitted by the company for the proposed clinical trials. From a practical standpoint, the FDA often dictates the nature of the protocols. The clinical trial process consists of three phases. Phase 1 trials are designed to elicit information about "the metabolism and pharmacologic actions of the drug in humans, [and] the side effects associated with increasing doses ....997 These tests are also intended to provide information on product safety. These Phase 1 trials typically involve tests on a small number of healthy adults-approximately twenty to eighty people.98 If the Phase 1 trials are successful, the company then proceeds to Phase 2 trials, which typically involve testing the drug on several hundred people who have the specific disease or condition for which the product is targeted.99 The Phase 2 trials are "conducted to evaluate the effectiveness of the drug for a particular indication or indications in patients with the disease or condition under

96. See 21 C.F.R. $\S \S 312.21-.22$ (1999).

97. Id. $\S 312.21$ (a)(1).

98. See id.

99. See id. $\$ 312.21(\mathrm{~b})$. 
study ...."100 In addition, these trials are intended to assess whether there are adverse side effects associated with the drug. 101 If the Phase 2 trials are also successful, the company proceeds to Phase 3 clinical trials involving from several hundred to several thousand patients who also have the specific condition or disease for which the drug is targeted.102 As the Phase 3 trials conclude, the company submits a new drug application (NDA) to the FDA to obtain permission to sell the pharmaceutical product. The NDA must include both safety and efficacy information; it is a compendium of all the data obtained during the three phases regarding the performance of the drug with respect to these two objectives. In addition, the NDA must include details on the proposed labeling for the new drug. 103

Before approving the drug, the FDA must determine that the drug is safe and that there is "substantial evidence" of the efficacy of the drug for its proposed uses. 104 Drugs are typically not risk-free, and prescription drugs are available by prescription only because of their risks. Before approving the drug, the FDA in effect makes a risk-benefit judgment that making the drug available is in society's best health interest. ${ }^{105}$ This process is so stringent that some critics of the FDA have suggested the onerous FDA process deprives patients of beneficial new drugs. 106

There have been some attempts to recognize that pharmaceuticals are quite different from other products. The drafters of the Restatement (Second)

100. Id.

101. See id.

102. See id. § $312.21(\mathrm{c})$.

103. For the requirements for a new drug application, see id. $\S 314.50$.

104. See 21 U.S.C. § 355(d) (1994 \& Supp. III 1997).

"[S]ubstantial evidence" means evidence consisting of adequate and well-controlled investigations, including clinical investigations, by experts qualified ... to evaluate the effectiveness of the drug involved, on the basis of which it could fairly and responsibly be concluded by such experts that the drug will have the effect it purports or is represented to have under the conditions of use prescribed, recommended, or suggested in the labeling or proposed labeling thereof.

Id.

105. See Bruce N. Kuhlik \& Richard F. Kingham, The Adverse Effects of Standardless Punitive Damage Awards on Pharmaceutical Development and Availability, 45 FOOD DRUG CoSM. L.J. 693, 694-97 (1990); Richard A. Merrill, Compensation for Prescription Drug Injuries, 59 VA. L. REV. 1, 1 (1973).

106. See, e.g., HENRY G. GRABOWSKI \& JOHN M. VERNON, THE REgULATION OF PHARMACEUTICALS: BALANCING THE BENEFITS AND RISKS 46-47 (1983); William M. Wardell, Introduction of New Therapeutics Drugs in the United States and Great Britain: An International Comparison, 14 Clinical Pharmacology \& Therapeutics 773, 787 (1973). But see William M. Wardell, Mohammed Hassar, Sadanand N. Anavekar \& Louis Lasagna, The Rate of Development of New Drugs in the United States, 1963 through 1975, 24 ClINICAL PHARMACOLOGY \& THERAPEUTICS 133, 139 (1978) (reporting that the FDA approved approximately $88 \%$ of NDAs submitted between 1963 and 1970). 
of Torts, in comment $\mathrm{k}$ to section $402 \mathrm{~A}$, indicated that strict liability was not meant to apply to "unavoidably unsafe products," for which drugs and vaccines serve as prominent examples:

k. Unavoidably unsafe products. There are some products which, in the present state of human knowledge, are quite incapable of being made safe for their intended and ordinary use. These are especially common in the field of drugs. An outstanding example is the vaccine for the Pasteur treatment of rabies, which not uncommonly leads to very serious and damaging consequences when it is injected. Since the disease itself invariably leads to a dreadful death, both the marketing and the use of the vaccine are fully justified, not withstanding the unavoidable high degree of risk which they involve. Such a product, properly prepared, and accompanied by proper directions and warnings, is not defective, nor is it unreasonably dangerous. The same is true of many other drugs, vaccines, and the like, many of which for this very reason cannot legally be sold except to physicians, or under the prescription of a physician. ${ }^{107}$

Notwithstanding the American Law Institute's position, courts have found that prescription drugs are not inherently dangerous. Rather, judges have generally applied comment $\mathrm{k}$ on a case-by-case basis.108 Moreover, courts have not recognized compliance with the requirements of the Federal Food, Drug, and Cosmetic Act as a complete defense to a product liability action. ${ }^{109}$ Only five states have recognized compliance with FDA requirements as a defense against punitive damages.110 I believe the regulatory compliance defense against punitive damages should be adopted more generally. Furthermore, it should be expanded to include all corporate risk analyses that comply with procedures established for the assessment of federal regulations and for which the costs of additional safety measures outweigh their benefits. Thus, in order to find a company liable, jurors would have to

107. RESTATEMENT (SECOND) OF TORTS $\S 402 \mathrm{~A} \mathrm{cmt.} \mathrm{k}$ (1965).

108. See, e.g., Hill v. Searle Lab., 884 F.2d 1064, 1069 (8th Cir. 1989) ("The drafters of comment $k$ did not intend to grant all manufacturers of prescription drugs a blanket exception to strict liability."); Toner v. Lederle Lab., 732 P.2d 297, 308 (Idaho 1987) (stating that comment k does not apply to all drugs, but rather applies"'when the situation calls for it"'); Feldman v. Lederle Lab., 479 A.2d 374, 380 (N.J. 1984) ("We do not agree that the protective shield of comment $k$ immunizes all prescription drugs. Moreover, we are of the opinion that generally the principle of strict liability is applicable to manufacturers of prescription drugs.").

109. Jeffrey N. Gibbs \& Bruce F. Mackler, Food and Drug Administration Regulation and Products Liability: Strong Sword, Weak Shield, 22 TORT \& INS. L.J. 194, 243 (1987) (stating that compliance with FDA regulation provides "only modest protection against the successful lawsuit"); Thomas Scarlett, The Relationship Among Adverse Drug Reaction Reporting, Drug Labeling, Product Liability, and Federal Preemption, 46 FOOD DRUG COSM. L.J. 31,39 (1991) (noting that compliance with government standards is merely a factor in determining liability).

110. The five states proscribing punitive damages in situations in which the manufacturer has complied with FDA requirements are: Arizona, ARIZ. REV. STAT. ANN. § 12-701 (West 1992); New Jersey, N.J. STAT. ANN. § 2A:58C-5c (West 1987); Ohio, OHIO REV. CODE ANN. § 2307.801(C)(1)(a) (Anderson 1998); Oregon, OR. REV. STAT. § 30.927 (1993); and Utah, UTAH CODE ANN. § 78-18-2(1) (1992). 
explicitly determine that either the risk analysis did not comply with the standards established by the U.S. government for regulatory evaluation or that the benefits of additional safety did in fact exceed the costs. For situations in which federal agencies have made explicit judgments along these lines, as in the instance of the Ford shoulder harness assessment, there would be no need to reassess the merits of the safety improvement.

Vaccines represent a classic case of risk-benefit tradeoffs: They typically the risk of an adverse reaction, but the vaccine itself has direct health benefits. FDA litigation over the diptheria, tetanus, and pertussis (DPT) vaccine in the 1980s reflects how jurors focus on the identified lives that are the object of the tort liability cases instead of the statistical lives that have been saved through a beneficial vaccine product.

On one hand, early estimates based on the medical literature in the early 1980 s indicated that the DPT vaccine was responsible for as many as twentyfive serious adverse reactions annually, including brain damage and some occasional deaths. It is now believed, however, that these early risk estimates were overstated.111 On the other hand, the vaccine offers substantial health benefits. A study by scientists at the Centers for Disease Control estimated that in the absence of the pertussis vaccine program, there would be approximately 322,000 additional cases of whooping cough per year, resulting in more than 400 additional annual deaths.112 Notwithstanding the FDA's judgment that the product passed a risk-benefit test, the DPT vaccine created a risk of multi-million dollar verdicts against the companies that produced it. The result was that manufacturers found it more attractive to abandon the vaccine market altogether than to incur this considerable liability hazard.113

111. See James D. Cherry, 'Pertussis Vaccine Encephalopathy': It Is Time to Recognize It As the Myth That It Is, 263 JAMA 1679, 1679 (1990) ("It is now the last decade of the 20th century, and it is time for the myth of pertussis vaccine encephalopathy to end."); Vincent A. Fulginiti, $A$ Pertussis Vaccine Myth Dies, 144 AM. J. DISEASES CHILDREN 860, 860 (1990) ("Over the years, I have been persuaded by a growing body of evidence that the so-called pertussis vaccine encephalopathy does not exist."); $c f$. Kim R. Wentz \& Edgar K. Marcuse, Diphtheria-Tetanus-Pertussis Vaccine and Serious Neurologic Illness: An Updated Review of the Epidemeologic Evidence, 87 PEDIATRICS 287, 295 (1991) ("There is an association between DTP vaccine and serious acute neurologic illness. The magnitude of this association is probably between 1 case of neurologic illness per 100,000 immunizations and 1 case per million immunizations.").

112. See Alan R. Hinman \& Jeffery P. Koplan, Pertussis and Pertussis Vaccine: Reanalysis of Benefits, Risks, and Costs, 251 JAMA 3109, 3112-13 (1984).

113. See Peggy J. Naile, Tort Liability for DPT Vaccine Injury and the Preemption Doctrine, 22 IND. L. REV. 655, 703 (1989) (explaining that large damages awards "are ... likely to induce manufacturers to abandon the vaccine market altogether"). 
Liability hazards led many firms to exit the vaccine market.114 Now there are only single-product monopolies supplying many of the vaccines for major illnesses, including polio, measles, rabies, mumps, and rubella. This monopoly pattern includes many pediatric vaccines as well. 115 In addition, the litigation has caused vaccine prices to surge because higher liability costs to manufacturers raised the marginal cost of supplying vaccines. 116 Economic theory suggests that increased immunization costs may have caused a decline in vaccination rates in the United States.117

The importance of an expanded regulatory compliance defense can be seen by examining the extent to which pharmaceuticals have been the target of litigation despite the FDA's view that such products on balance are beneficial. Table 5 summarizes several examples of punitive damages cases. Oral contraceptives, for example, have long been a target of litigation, leading to substantial liability awards.118 Indeed, the National Academy of Science has concluded that litigation for oral contraceptives was sufficiently onerous that it served as a principal deterrent for the development of new contraceptive devices in the United States. ${ }^{119}$

Another prominent example is the Bendectin litigation. Bendectin was a prescription drug that pregnant woman took from 1957 to 1983 to reduce the symptoms of morning sickness. An estimated thirty million women took this drug. ${ }^{120}$ The FDA approved Bendectin in 1956, and is still approved for use today. ${ }^{121}$ Although the FDA concluded that pregnant women's use of Ben-

114. See generally AM. MED. ASS'N BD. OF TRUSTEES, Impact of Product Liability on the Development of New Medical Technologies, 137 AM. MED. ASS'N PROC. HOUSE OF DELEGATES 79, 83-86 (1988) (discussing the impact of product liability on vaccine manufacturers).

115. See generally Vaccine Injury Compensation: Hearing on H.R. 1780, H.R. 4777, and H.R. 5184 Before the Subcomm. on Health and the Environment of the House Comm. on Energy and Commerce, 99th Cong. 113-14 (1987) (statement of Representative Fred J. Eckert) (describing a serious decline in the number of vaccine manufacturers in the United States).

116. See AM. MED. ASS'N BD. OF TRUSTEES, supra note 114, at 7; see also Gina Kolata, Litigation Causes Huge Price Increases in Childhood Vaccines, 232 SCIENCE 1339, 1339 (1986) (documenting the huge increase in DPT vaccine prices and the large portion of the price going toward product liability insurance).

117. See Sara Rosenbaum, Rationing Without Justice: Children and the American Health System, 140 U. PA. L. REV. 1859, 1867-68 (1992).

118. See e.g., Wooderson v. Ortho Pharm. Corp., 681 P.2d 1038, 1038 (Kan. 1984).

119. See NAT'L RES. COUNCIL \& INST. OF MED., DEVELOPING NEW CONTRACEPTIVES: OBSTACLES AND OPPORTUNITIES 141 (1991) (finding that the unpredictable nature of litigation is a significant disincentive for contraceptive research and development).

120. See Richardson v. Richardson-Merrell, Inc., 857 F.2d 823, 824 (D.C. Cir. 1988) (stating that 30 million pregnant women used Bendectin between 1957, when it was first marketed and 1983, when Richardson-Merrell discontinued marketing the drug).

121. See id. at 824; KENNETH R. FOSTER \& PETER W. HubER, JudGING SCIENCE: SCIENTIFIC KNOWLEDGE AND THE FEDERAL COURTS 24 (1997). 
dectin is safe for their unborn children, 122 the wave of Bendectin litigation ultimately cost manufacturers so much that they stopped marketing the product. Although no jury verdict that Bendectin causes birth defects has ever been upheld on appeal, plaintiffs have received a favorable verdict in approximately $36 \%$ of the cases that have gone to trial.123 The risk of juror error coupled with high litigation costs led manufacturers to withdraw Bendectin from the market notwithstanding the continuing assessment by the FDA and the scientific community that Bendectin provides benefits exceeding its risks.

The Bendectin cases are particularly noteworthy in that the punitive damages awards are often substantial-as high as $\$ 75$ million in one instance. But the Bendectin cases are also distinctive in that the punitive damage awards, and in some cases the verdicts themselves, have been overturned on appeal. Merrell Dow Pharmaceuticals also incurred substantial litigation costs to fend off these potentially catastrophic lawsuits.

Not all the defendants succeeded in avoiding damage awards. In the last case listed in Table 5, for example, the jury awarded not only compensatory damages of $\$ 9$ million, but also punitive damages of $\$ 35$ million. Moreover, in that situation there was an additional lawsuit against the physician, who paid $\$ 500,000$ in compensatory damages and $\$ 23.5$ million in punitive damages.

There are three principal messages conveyed by the cases listed in Table 5. First, compensatory damages involving pharmaceuticals often range in the millions. Companies must pay these damages notwithstanding the FDA drug approval process. Second, juries often award punitive damages that are larger than the compensatory damages and that are inconsistent with regulatory compliance. Finally, courts often recognize the inappropriateness of punitive damages and frequently overturn these awards. But the appeals process is expensive, and risk-averse companies may settle out of court

122. This conclusion is consistent with the scientific community's position as well. See, e.g., Turpin v. Merrell Dow Pharm., Inc., 959 F.2d. 1349, 1353-56 (6th Cir. 1992) (describing 35 epidemiological studies which found no evidence that Bendectin caused birth defects); Wilson v. Merrell Dow Pharm., Inc., 893 F.2d 1149, 1154-55 (10th Cir. 1990) (affirming a judgment n.o.v. for the manufacturer based in part on approximately 40 epidemiological studies that failed to find a connection between Bendectin and birth defects).

123. For a review of Bendectin litigation, see generally Joseph Sanders, Jury Deliberation in a Complex Case: Havner v. Merrell Dow Pharmaceuticals, JUST. Sys. J., March 1993, at 45 (analyzing jury deliberations in the Havner case); Joseph Sanders, The Bendectin Litigation: A Case Study in the Life Cycle of Mass Torts, 43 HASTINGS L.J. 301 (1992) (exploring the rapid decline in the rate of plaintiffs' success in Bendectin lawsuits). 
rather than face the legal and financial uncertainties involved with such highstakes lotteries.

In some of the cases listed in Table 5 the plaintiff suggested that the defendant falsified lab reports, did inadequate testing, or failed to inform the FDA of side effects of the drug. If the company did in fact withhold or misrepresent significant information, then the FDA could impose regulatory sanctions. From a practical standpoint, pharmaceutical firms receive information about potential adverse reactions on a continuing basis. A single patient with an unfavorable outcome could lead to such a report. But without a large sample and a controlled experiment to determine that the drug caused the adverse outcome, the company may not have any information to report to the FDA. Once a pattern of adverse reactions becomes established, however, it becomes clear in hindsight that the earlier reports did signal a potential problem. Still, until a large amount of information becomes available, it is often impossible to make reliable judgments regarding adverse effects. Compensatory damages for the victim combined with sanctions imposed by the regulatory agency should be sufficient to deter companies from deceiving the FDA.

The examples I have discussed are not isolated incidents, but reflect a broader pattern of litigation against the pharmaceutical industry. Many drugs that remedy health problems have adverse side effects; society's task is to select those drugs with net beneficial health effects. The FDA's approval process is designed to help us do so. The difficulty is that jurors often second-guess these judgments, making the pharmaceutical industry a leading target for tort actions.

Consider the performance of the pharmaceutical industry during the peak of the liability crisis, from 1984 to 1986.124 The pharmaceutical industry was subject to more liability suits in federal courts 125 and higher mean damages awards relative to sales than the rest of the U.S. manufacturing sector. ${ }^{126}$ Moreover, the ratio of liability costs to sales for the pharmaceutical industry dwarfed that for the rest of the manufacturing industries in the U.S.127 Rather than being immune from liability, pharmaceuticals became the principal target during the liability cost explosion. This pattern diminished

124. The statistics cited in this paragraph are based on the evidence for the U.S. federal courts presented in W. Kip Viscusi, Michael J. Moore \& James Albright, A Statistical Profile of Pharmaceutical Industry Liability, 1976-1989, 24 SETON HALL L. REV. 1418 (1994).

125. See id. at 1421 fig. 1.

126. See id. at 1433 fig. 7 . Indeed, in 1985 , total awards for the pharmaceutical industry exceeded those for the rest of the manufacturing sector. See id. at 1431 fig. 6.

127. See id. at 1433 fig. 7. 
thereafter as firms began to settle more cases out of court.128 Nevertheless, the threat of ruinous liability remains.

What the pharmaceutical experience demonstrates is that even when a risk-benefit analysis was subject to rigid government guidelines, and was approved after a careful review by the appropriate government authority, manufacturers remain exposed to the risk that jurors will second-guess the safety of their products. Moreover, since jurors will tend to focus on the actual lives harmed by a product rather than on statistical data regarding expected lives saved, they will tend to impose excessive punishments.

The most important lesson of the pharmaceutical experience is that formalization of a regulatory compliance defense could serve a constructive role. The rationale for expanding the regulatory compliance defense against punitive damages is quite strong. Moreover, a similar defense should be available to corporations in other industries that conduct risk analyses in compliance with government regulations. Although I will suggest broader policy reforms in the concluding section, even a limited reform of this nature would help ensure that sound corporate risk analyses serve an exculpatory function rather than as a trigger for punitive damages.

\section{CONCLUSION}

A major puzzle raised by the performance of the courts is that many of the most well-known cases involving punitive damages are also those in which corporations undertook a risk analysis, or in some cases, a sound benefit-cost analysis. In those cases, jurors chose to award punitive damages even though thorough internal risk analyses led the defendants to conclude that no additional safety improvements were warranted. This result is the opposite of what would occur if the legal system fostered better corporate risk behavior. More rational thinking about risk and a conscientious effort to achieve risk-cost balancing in line with society's valuation of safety should signal corporate responsibility rather than trigger corporate punishment. As Judge Easterbrook has observed, corporations are well positioned to undertake such risk analyses and routinely do so in a manner that reflects a degree of technical knowledge and judgment that a jury is unlikely to share.129

Why do jurors make the mistake of punishing corporations for risk-cost balancing? A variety of conjectures are possible. People may be averse to

128. See id.

129. See Carroll v. Otis Elevator Co., 896 F.2d 210, 215 (7th Cir. 1990). 
explicitly balancing money against human lives. Money and lives might be considered incommensurable. Or, jurors might not be adequately trying to place themselves in the shoes of the corporation at the time of the tradeoff decision. At the time of the decision, the corporation sees only a small probability of an accident, not a certainty. In hindsight, a small corporate expenditure would have prevented an identifiable death, whereas ex ante the corporation would have had to make that expenditure thousands if not millions of times to decrease the risk of an abstract person's death. Comparisons involving identified victims and safety costs will overwhelm jurors' sensibilities, particularly for low-probability events with severe consequences. When corporations systematically think about risk levels yet nevertheless pursue product or environmental policies that fail to maximize safety, the juror may regard the corporate decision as "cold-blooded." This difficulty arises, in part, because of the well-documented role of hindsight bias with respect to retrospective risk judgments.130 What matters at the time of the corporate decision is a comparison of the costs of the safety measure with its expected benefits, which consist of the reduced probability of an accident multiplied by the value of the likely damage from an accident. But as Judge Easterbrook observed, jurors tend not to compare the expected benefits and costs. Rather, after the victim has been identified, they simply compare the loss to the victim against the costs to save that individual, neglecting the fact that before the accident the loss was only an abstract probability.

How does such a hindsight bias play out with respect to particular cases? For the Ford Pinto, the comparison is between a cost of $\$ 11$ per car to move the gas tank and the life of the victim of an exploding Pinto. For the GM fuel tank placement, the comparison is between the $\$ 2.20$ cost per new car sold and an identifiable burn death. Once such comparisons are made, the corporation's decision not to undertake the safety improvement appears ludicrous, reckless, and irresponsible. But before the accidents occur, the appropriate comparison is between the expected value of the losses that will occur if the safety improvement is not undertaken and the total cost over the entire product line of undertaking the safety measure, which will not be as stark a comparison and may have the opposite implications. These benefit-cost comparisons also avoid the purely retrospective focus on the identified life lost after the fact. Instead, it takes the jury back to the time of the corporate decision.

130. See Reid Hastie, David A. Schkade \& John W. Payne, Juror Judgments in Civil Cases: Hindsight Effects on Judgments of Liability for Punitive Damages, 23 LAW \& HUM. BEHAV. 597 (1999). 
The mock juror analysis made it possible to isolate which factors affected juror beliefs and how they were influential. The most consistent result across the different scenarios was that undertaking any type of risk analysis was harmful to the corporation's prospects both with respect to the probability of punitive damages and, more importantly, with respect to the magnitude of the award. Using a willingness-to-pay value of life rather than the compensatory damages value has the perverse effect of anchoring juror awards at a higher level. Risk analyses and, in particular, analyses that value lives highly, are harmful to the company's prospects, whereas failing to think systematically about risks and undervaluing life is a less costly corporate strategy. The resulting incentives are perverse.

The mock juror analysis also demonstrated the factors that did not affect participants' judgments on punitive damage awards. The expense of providing for greater safety should have affected their attitudes, but did not. Similarly, the total number of deaths might have been a concern, but was not. This is not clearly a bad result: Increasing the number of deaths and costs proportionally merely changes the scale of the problem, and does not affect whether a particular safety feature is worth its costs. Finally, whether the corporation undertook an erroneous benefit-cost analysis or did the analysis correctly did not significantly affect the mock jurors' assessment of damages. That mock jurors did not respond sensibly to these factors, which on their face should be influential, highlights the value of examining how jurors actually behave, instead of simply hypothesizing about their behavior.

It is noteworthy that in the survey scenarios in which a benefit-cost analysis was supplied and the appropriate value of life was used, the costs of the safety measure exceeded their benefits. This result has important implications for the appropriate liability of the firm. If the costs of the safety measure exceed the benefits, the company is not negligent in failing to adopt it, much less guilty of reckless behavior that would warrant punitive damages. But undertaking this kind of responsible risk analysis indicates that the company knew of the risk and intentionally inflicted it on a probabilistic basis, thus triggering punitive damages in the view of the mock jurors.

The solution to such jury misbehavior is not a narrowly defined legal reform. It would not be appropriate to exempt a corporation from punitive damages merely because it undertook a risk analysis, because the quality and pertinence of the analysis may be insufficient. But corporate risk analyses in compliance with federal regulatory guidelines, such as those completed during the FDA approval process, should be given a statutory defense against punitive damages. Such a measure would begin to address current biases. 
Rewriting jury instructions for punitive damages does not seem to be a reasonable solution, since the difficulties arise from cognitive biases and systematic errors that people make in thinking about risk. The problem is that jurors are generally not able to make the subtle economic judgments that should be involved in determining whether punitive damages are awarded and, if so, how much the award should be. Moreover, rewriting instructions for juries may not be effective if juries ignore such directives or interpret them in a manner that fits their desired objectives. The independent character of jurors is reflected by the fact that three-fourths of all people agree with the statement: "Whatever a judge said the law is, jurors should do what they believe is the right thing." 131

There have been a variety of legal reform efforts directed at restraining punitive damages; those that have been adopted thus far focus primarily on capping them. But caps do not eliminate the fundamental irrationality that juries display with respect to punitive damage awards. An alternative proposal is to transfer the responsibility for awarding punitive damages from jurors to judges. That proposal would remedy jurors' behavior, but would not be a total solution because judges are not fully rational in their handling of risk either. ${ }^{132}$ Elsewhere, I have proposed abolishing punitive damages for corporate safety and environmental torts. My underlying rationale is that compensatory damages coupled with market forces and vigorous regulatory enforcement regimes would be provide adequate incentives to stop companies from marketing unreasonably dangerous products. Moreover, there is no statistically significant evidence that abolishing punitive damages would have any effect on any of a wide variety of measures of safety, ranging from the rate of toxic chemical spills to product accident rates. ${ }^{133}$

Because jurors do not evaluate risk analyses and benefit-cost assessments properly, they are not well suited to assess this central component of corporate action. This inadequacy provides an additional rationale for transferring the responsibility for deterring corporate misbehavior from the courts to regulatory agencies. Analyses of the risk consequences of safety designs or corporate decisions often involve complex technical judgments and sophisticated economic analyses, which in many instances exceed the compe-

131. Bob Van Voris, Civil Cases: Jurors Do Not Trust Civil Litigants. Period., NAT'L L.J., Nov. 2, 1998, at A24. (2000).

132. See W. Kip Viscusi, How Do Judges Think About Risk?, 1 AM. L. \& ECON. REV. 26

133. See generally W. Kip Viscusi, Why There Is No Defense of Punitive Damages, 87 GEO. L.J. 381 (1998); W. Kip Viscusi, The Social Costs of Punitive Damages Against Corporations in Environmental and Safety Torts, 87 GEO. L.J. 285 (1998). 
tence of jury members selected from the population at random. Indeed, the U.S. Office of Management and Budget has issued detailed economic guidelines for how agencies should prepare such assessments. ${ }^{134}$ These guidelines often require complex economic judgments. Government agencies routinely make these judgments as part of every major new rulemaking. Indeed, they have been required by executive orders of the President to undertake such analyses for several decades. ${ }^{135}$ It is not surprising that jurors without training and background fail to make technical economic judgments in a sound manner. What is more disturbing, however, is that sound economic analyses are not simply treated in a random fashion by jurors but actually damage companies' prospects in court.

\section{APPENDIX}

\section{Sample Description}

The sample of 489 adults was recruited by a survey research firm in Phoenix, Arizona. Subjects were paid an average of $\$ 40$ to participate in a one-and-a-half hour survey. Subjects came to a central location where they participated in this survey. The scenarios discussed in this paper were the first questions in a longer written survey dealing with risk and legal issues. The average participant took fifteen minutes to complete the survey.

Table A summarizes the sample characteristics. Overall, $68 \%$ of the sample was female; the average age was forty-five. In terms of racial background, $80 \%$ of the sample was white, $5 \%$ was Hispanic, and the remainder consisted of other minorities.

The educational level of the sample varied greatly: $4 \%$ of the sample had not completed high school; $11 \%$ of the sample had professional degrees. The largest educational group represented was that of people who had some college education; this group comprised $40 \%$ of the sample.

The smoking status variable is in line with national estimates: $23 \%$ of the sample were current smokers and an equal percentage were former smokers.

In addition to smoking, the other indicator of risk preference was seatbelt use; $80 \%$ of the sample indicated that they always use seatbelts while driving or riding in a car.

134. See, e.g., U.S. OFFICE OF MANAGEMENT \& BUDGET, supra note 15, at 634.

135. See, e.g., Exec. Order No. 12,866, 3 C.F.R. 638 (1993); Exec. Order No. 12,291, 3 C.F.R. 127 (1981). 
The sample was not nationally or regionally representative, but it did include a diverse population mix. Additional statistical analysis using models to control for the separate influences at work yields estimates of the incremental effect of the scenario manipulations, controlling for the influence of personal characteristics. These effects are almost identical to those reflected in the summary of the overall sample mean effects in Table 3.

Although the text described results for the mean response levels, regression analyses yielded similar results. These regressions took into account respondents' gender, age, race, education, smoking status, and seatbelt use.136 Controlling for personal characteristics in regression estimates undertaken by the author but not reported here, the probability that a juror would award punitive damages increases by $5 \%$, the same as when personal characteristics are not taken into account. There is a modest effect on the level of punitive damages award, however. Without controlling for personal characteristics, undertaking a benefit-cost analysis increases the punitive damages award by $47 \%$, whereas this value is only $39 \%$ when personal characteristics are taken into account. 


\section{TABLE 1}

\section{JUROR RISK SURVEY VARIATIONS}

\begin{tabular}{|c||c|}
\hline Scenario & \multicolumn{1}{|c|}{ No Benefit-Cost Analysis } \\
\hline & No analysis performed, \$4 million cost-per-life-saved. \\
\hline $\mathbf{1}$ & No analysis performed, \$1 million cost-per-life-saved. \\
\hline & \multicolumn{1}{|c|}{ Benefit-Cost Analysis Performed } \\
\hline 3 & $\begin{array}{l}\text { Analysis using \$800,000 compensatory damages amount to value } \\
\text { life, \$4 million cost-per-life-saved. }\end{array}$ \\
\hline 4 & $\begin{array}{l}\text { Analysis using NHTSA value of life figure of } \$ 3 \text { million to value } \\
\text { life, } \$ 4 \text { million cost-per-life-saved. }\end{array}$ \\
\hline $\mathbf{5}$ & $\begin{array}{l}\text { Erroneous analysis using NHTSA value of life figure of } \$ 3 \text { mil- } \\
\text { lion to value life, estimated cost-per-life-saved of } \$ 4 \text { million but } \\
\text { actual amount was } \$ 2 \text { million. }\end{array}$ \\
\hline
\end{tabular}

\begin{tabular}{|c|l|}
\hline Survey Waves & \\
\hline 1 & Total lives lost was 10. \\
\hline 2 & Total lives lost was 4. \\
\hline
\end{tabular}




\section{TABLE 2}

SUMMARY OF EXPERIMENTAL STRUCTURE, HYPOTHESES, AND RESULTS

\begin{tabular}{|c|c|c|}
\hline Experimental Test & Hypothesis & Finding \\
\hline $\begin{array}{l}\text { Scenario } 1 \text { vs. } \\
\text { Scenario } 2\end{array}$ & $\begin{array}{l}\text { Jurors will impose greater } \\
\text { sanctions (i.e., increased } \\
\text { frequency and magnitude of } \\
\text { punitive damages) if safety } \\
\text { improvements are cheaper, or } \\
\text { a lower cost-per-life-saved. }\end{array}$ & $\begin{array}{l}\text { No significant effect. } \\
\left(t_{\mathrm{PROB}}=1.58 ; \mathrm{t}_{\mathrm{AMT}}=0.100\right)\end{array}$ \\
\hline $\begin{array}{l}\text { Scenario } 1 \text { vs. } \\
\text { Scenarios } 3,4,5\end{array}$ & $\begin{array}{l}\text { Jurors will impose greater } \\
\text { sanctions if firms undertake a } \\
\text { risk analysis related to } \\
\text { subsequent accidents. }\end{array}$ & $\begin{array}{l}\text { Significant effect with large } \\
\text { influence on award level. } \\
\left(\mathrm{t}_{\mathrm{PROB}}=2.78^{* * *} ; \mathrm{t}_{\mathrm{AMT}}=1.85^{*}\right)\end{array}$ \\
\hline $\begin{array}{l}\text { Scenario } 3 \text { vs. } \\
\text { Scenario } 4\end{array}$ & $\begin{array}{l}\text { Jurors will not be as likely to } \\
\text { punish corporate risk analysis } \\
\text { using a higher value of life } \\
\text { and in line with government } \\
\text { regulatory practices. } \\
\text { Alternative hypothesis: } \\
\text { Higher value of life measures } \\
\text { by the company serve as an } \\
\text { anchor that boosts damages } \\
\text { awards. }\end{array}$ & $\begin{array}{l}\text { Significant effect in the } \\
\text { "wrong" direction as awards } \\
\text { increase with value of life } \\
\text { used. } \\
\left(\mathrm{t}_{\mathrm{PROB}}=0.08 ; \mathrm{t}_{\mathrm{AMT}}=1.05\right. \\
\left.\mathrm{t}=3.36^{* * *}\right)\end{array}$ \\
\hline $\begin{array}{l}\text { Scenario } 4 \text { vs. } \\
\text { Scenario } 5\end{array}$ & $\begin{array}{l}\text { Juries will impose greater } \\
\text { sanctions if corporations } \\
\text { make errors in their risk } \\
\text { analysis. }\end{array}$ & $\begin{array}{l}\text { No significant effect. } \\
\left(\mathrm{t}_{\mathrm{PROB}}=0.50 ; \mathrm{t}_{\mathrm{AMT}}=0.60\right)\end{array}$ \\
\hline $\begin{array}{l}\text { Scenarios } 1-5 \text { ( } 10 \text { deaths) vs. } \\
\text { Scenarios } 1-5 \text { ( } 4 \text { deaths) }\end{array}$ & $\begin{array}{l}\text { Juries will impose greater } \\
\text { sanctions if the number of } \\
\text { lives lost is greater. }\end{array}$ & $\begin{array}{l}\text { No significant effect. } \\
\left(\mathrm{t}_{\mathrm{PROB}}=0.80 ; \mathrm{t}_{\mathrm{AMT}}=0.43\right)\end{array}$ \\
\hline
\end{tabular}

Notes: $t_{\mathrm{RROB}}$ is the t-statistic for the difference in punitive award probability means.

$t_{A M T}$ is the $t$-statistic for the difference in award level geometric means.

* - statistically significant at $10 \%$ level, two-tailed test

** - statistically significant at $5 \%$ level, two-tailed test

*** - statistically significant at $1 \%$ level, two-tailed test 
TABLE 3

JURORS' REACTIONS TO AUTOMOTIVE NEGLIGENCE CASE

Panel A: Scenarios with no Benefit-Cost Analysis by Company

\begin{tabular}{|c|c|c|c|c|}
\hline $\begin{array}{l}\text { Version of } \\
\text { survey }\end{array}$ & $\begin{array}{c}\text { Sample } \\
\text { size }\end{array}$ & $\begin{array}{c}\text { Percent of } \\
\text { sample favoring } \\
\text { punitive } \\
\text { damages }\end{array}$ & $\begin{array}{l}\text { Goometris } \\
\text { mean of } \\
\text { awards } \\
\text { ( } \$ \text { millians) }\end{array}$ & $\begin{array}{l}\text { Nicaton } \\
\text { avarat }\end{array}$ \\
\hline $\begin{array}{l}\$ 4 \text { million/life } \\
\text { (Scenario 1) }\end{array}$ & 97 & .845 & 2.95 & 1.0 \\
\hline $\begin{array}{l}\$ 1 \text { million/life } \\
\text { (Scenario 2) }\end{array}$ & 97 & .918 & 2.86 & 1.0 \\
\hline $\begin{array}{l}\text { Combined no analysis } \\
\text { by company }\end{array}$ & 194 & .881 & 2.91 & 1.0 \\
\hline
\end{tabular}

Panel B: Scenarios with Benefit-Cost Analysis by Company

\begin{tabular}{|c|c|c|c|c|}
\hline $\begin{array}{l}\text { Version of } \\
\text { survey }\end{array}$ & $\begin{array}{l}\text { Sample } \\
\text { size }\end{array}$ & $\begin{array}{l}\text { Percent of } \\
\text { sample favoring } \\
\text { panitive } \\
\text { damagas }\end{array}$ & $\begin{array}{l}\text { Geometis } \\
\text { mean of } \\
\text { awards } \\
\text { (\$ millons) }\end{array}$ & 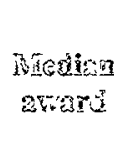 \\
\hline $\begin{array}{l}\text { Court costs as value } \\
\text { (Scenario 3) }\end{array}$ & 97 & .928 & 4.02 & 3.5 \\
\hline $\begin{array}{l}\text { NHTSA value of life } \\
\text { (Scenario } 4 \text { ) }\end{array}$ & 102 & .931 & 5.31 & 10.0 \\
\hline $\begin{array}{l}\text { NHTSA value of life, } \\
\text { error (Scenario 5) }\end{array}$ & 96 & .948 & 4.50 & 10.0 \\
\hline $\begin{array}{l}\text { Combined analysis } \\
\text { by company }\end{array}$ & 295 & .936 & 4.59 & 10.0 \\
\hline
\end{tabular}

Panel C: Full Sample Results

\begin{tabular}{|c|c|c|c|c|}
\hline $\begin{array}{l}\text { Version of } \\
\text { survey }\end{array}$ & $\begin{array}{c}\text { Sample } \\
\text { size }\end{array}$ & $\begin{array}{l}\text { Percent of } \\
\text { sample favoring } \\
\text { panicive } \\
\text { damages }\end{array}$ & $\begin{array}{l}\text { Geometric } \\
\text { mean of } \\
\text { awards } \\
\text { (S millions) }\end{array}$ & 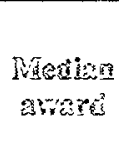 \\
\hline $\begin{array}{l}\text { Total for all five } \\
\text { scenarios }\end{array}$ & 489 & .914 & 3.85 & 5.0 \\
\hline
\end{tabular}

$t$-test (punitive damages frequency): $t=2.0958^{\text {t* }}$

$\mathrm{t}$-test (In punitive damages amount): $\mathrm{t}=2.4431$ * 
TABLE 4

BENEFIT-COST CALCULATIONS FOR THE FORD PINTO

Panel A: Benefit calculations for increased safety in Pinto gas tank design

\begin{tabular}{|l|c|c|}
\hline \multicolumn{1}{|c|}{ Outcome of faulty design } & Ford's unit value & Ford's total value \\
\hline \hline 180 burn deaths & $\$ 200,000$ & $\$ 36$ million \\
\hline 180 serious burn injuries & $\$ 67,000$ & $\$ 12.1$ million \\
\hline 2,100 burned vehicles & $\$ 700$ & $\$ 1.5$ million \\
\hline \multicolumn{1}{|c|}{ Total } & & $\$ 49.6$ million \\
\hline
\end{tabular}

Panel B: Cost calculations for increased safety in Pinto gas tank design

\begin{tabular}{|l|c|c|}
\hline \multicolumn{1}{|c|}{ Number of units } & Unit cost & Total cost $^{\mathbf{2}}$ \\
\hline 11 million cars & $\$ 11$ & $\$ 121$ million \\
\hline 1.5 million light trucks & $\$ 11$ & $\$ 16.5$ million \\
\hline Total & & $\$ 137.5$ million \\
\hline
\end{tabular}

a Excluded is the minor cost component of the lost consumer's surplus of customers who do not buy Pintos because of the $\$ 11$ price increase. 


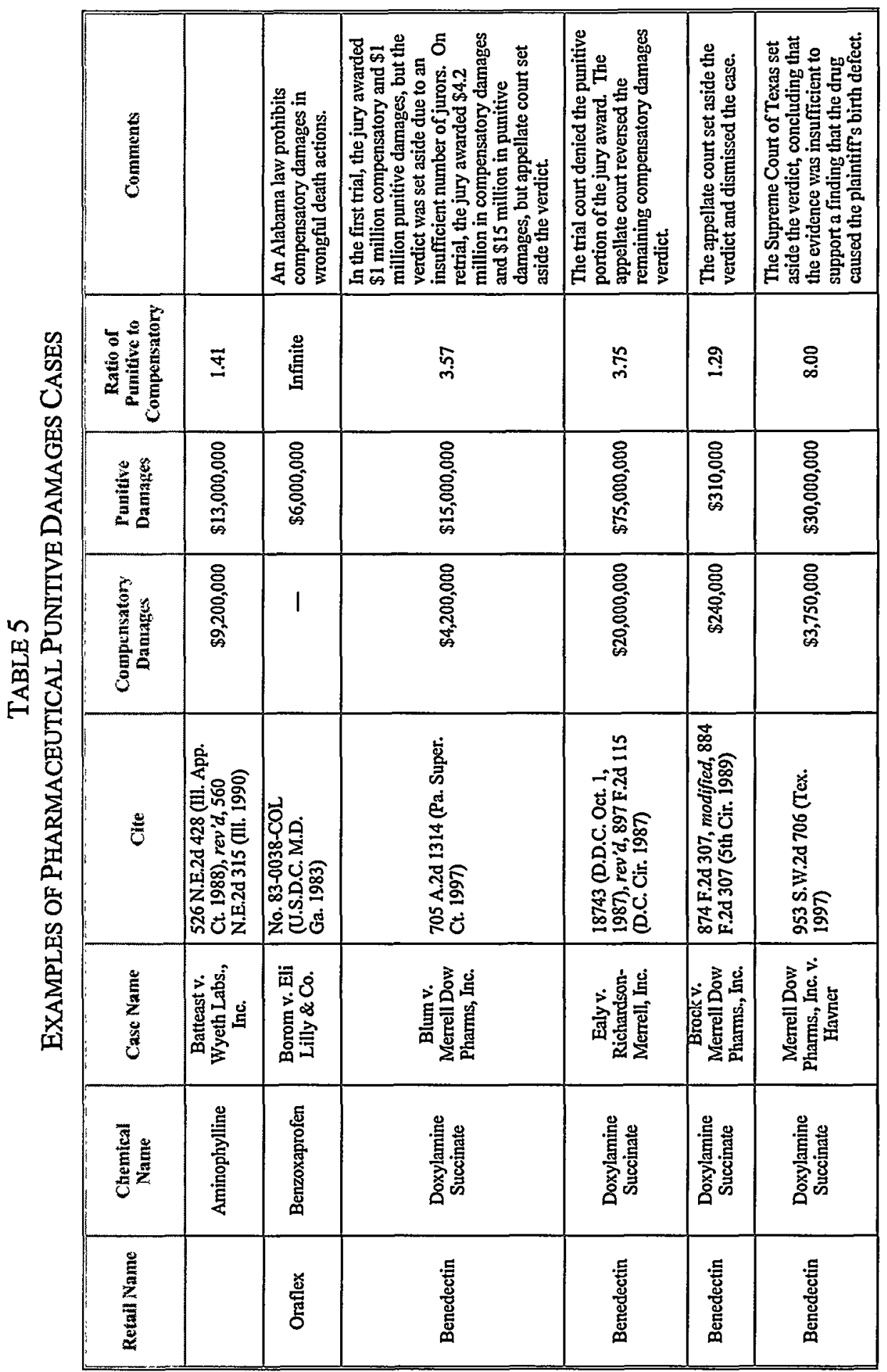




\begin{tabular}{|c|c|c|c|c|c|c|c|}
\hline 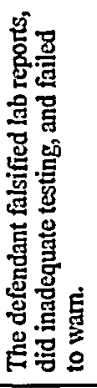 & & 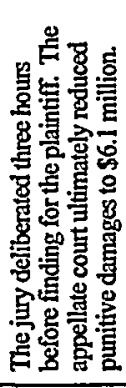 & 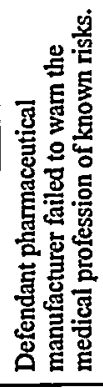 & 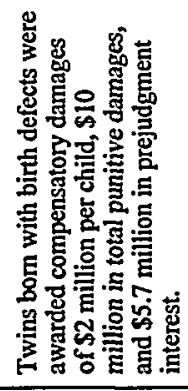 & 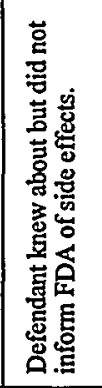 & 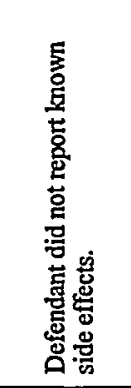 & 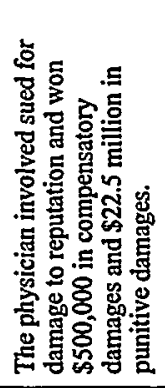 \\
\hline 욱 & গુ̆ & $\overrightarrow{\widehat{\delta}}$ & $\underset{\sim}{\stackrel{m}{్}}$ & $\underset{i}{J}$ & $\underset{\sim}{\mathbb{S}}$ & $\underset{\text { i }}{8}$ & $\underset{\sim}{\mathfrak{m}}$ \\
\hline 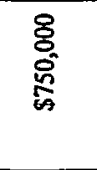 & 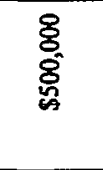 & 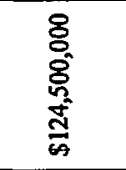 & 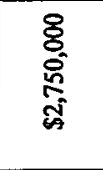 & 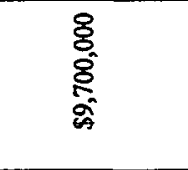 & 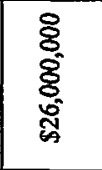 & 怘 & 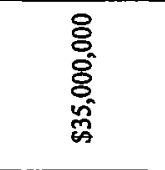 \\
\hline 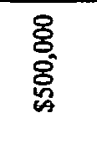 & 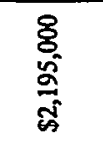 & 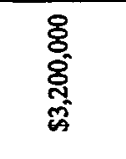 & 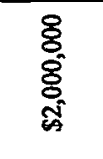 & 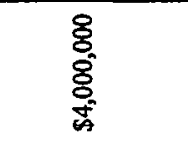 & 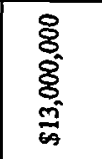 & 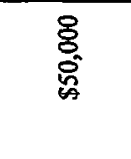 & 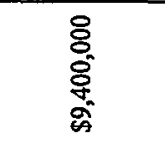 \\
\hline 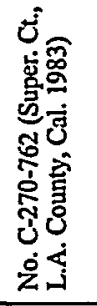 & 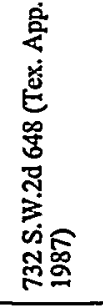 & 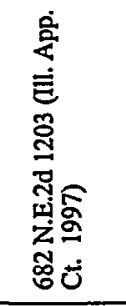 & 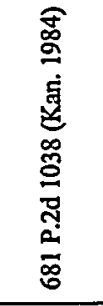 & 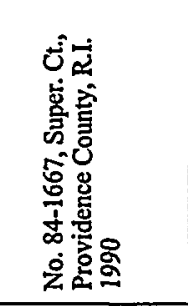 & 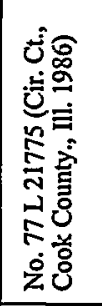 & 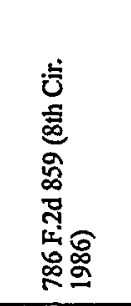 & 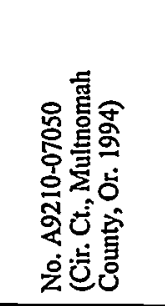 \\
\hline 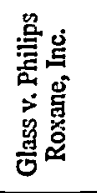 & 完总总 & 离. & 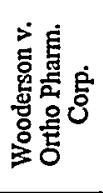 & 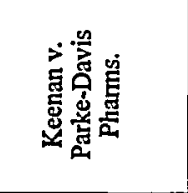 & 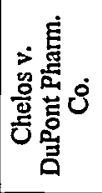 & 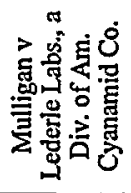 & 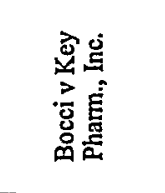 \\
\hline 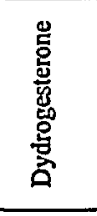 & 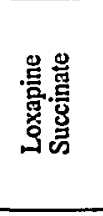 & 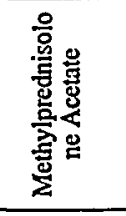 & 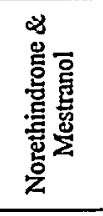 & 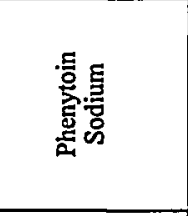 & 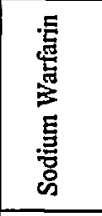 & 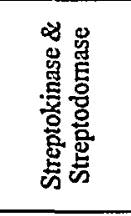 & $\begin{array}{l}\text { 总 } \\
\text { 言 } \\
\text { 言 } \\
\text { 总 }\end{array}$ \\
\hline 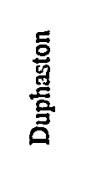 & $\begin{array}{l}0 \\
\frac{5}{30} \\
0\end{array}$ & 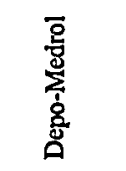 & 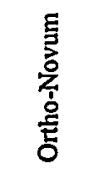 & 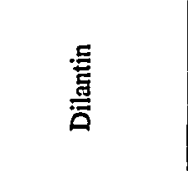 & 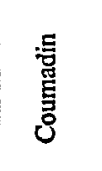 & 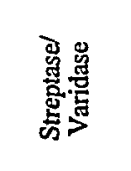 & \\
\hline
\end{tabular}


HeinOnline -- 52 Stan. L. Rev. 598 1999-2000 